NBER WORKING PAPER SERIES

\title{
ROBIN HOOD AND HIS NOT-SO-MERRY PLAN: CAPITALIZATION AND THE SELF-DESTRUCTION OF TEXAS' SCHOOL FINANCE EQUALIZATION PLAN
}

\author{
Caroline M. Hoxby \\ Ilyana Kuziemko \\ Working Paper 10722 \\ http://www.nber.org/papers/w10722 \\ NATIONAL BUREAU OF ECONOMIC RESEARCH \\ 1050 Massachusetts Avenue \\ Cambridge, MA 02138
}

August 2004

\begin{abstract}
All errors are the authors' own. Nevertheless, they gratefully thank the Russell Sage Foundation's Special Project on Social Inequality for generous support and also thank the MacArthur Foundation's Inequality Network for support. The authors gratefully acknowledge helpful comments from Douglas Bernheim, Michael Boskin, Edward Glaeser, Joseph Gyourko, Jonathan Gruber, Robert Inman, Brigitte Madrien, Thomas Nechyba, James Poterba, Antonio Rangel, Todd Sinai, seminar participants at Harvard University, MIT, Stanford University, The University of California - Berkeley, Wharton, and the National Bureau of Economic Research. For help with data, the authors are especially grateful to Doug Smith of the Texas Education Agency, Division of State Funding. In addition, the authors gratefully acknowledge the many helpful conversations they have had with Texans, who have helped them to appreciate the state's special circumstances. The views expressed herein are those of the author(s) and not necessarily those of the National Bureau of Economic Research.
\end{abstract}

(C2004 by Caroline M. Hoxby and Ilyana Kuziemko. All rights reserved. Short sections of text, not to exceed two paragraphs, may be quoted without explicit permission provided that full credit, including (C) notice, is given to the source. 
Robin Hood and His No-So-Merry Plan: Capitalization and the Self-Destruction of Texas'

School Finance Equalization Plan

Caroline M. Hoxby and Ilyana Kuziemko

NBER Working Paper No. 10722

August 2004

JEL No. H2, H24, H7, H71, H72, I2, K11, R5

\begin{abstract}
School finance schemes control the allocation of $\$ 370$ billion a year in the United States, but their economics are poorly understood. We examine an illuminating example: Texas' "Robin Hood" scheme, which was enacted in 1994 , allocates about $\$ 30$ billion a year, and is currently collapsing and likely to be abandoned. We show that the collapse was predictable. Robin Hood's design causes substantial negative capitalization, shrinking its own tax base. It relies only slightly on relatively efficient (pseudo lump sum) redistibution and heavily on high marginal tax rates. Although Robin Hood reduced the spending gap between Texas' property-poor and property-rich districts by $\$ 500$ per pupil, it destroyed about $\$ 27,000$ per pupil in property wealth. The magnitude of this loss is important: if the state had efficiently confiscated the same wealth and invested it, it would generate sufficient annual income to make all Texas schools spend at a high level. The Robin Hood scheme is stringent but not bizarre: other states' systems share its features to some degree. We provide estimates of the effects of school finance system parameters, which policy makers could use to design systems that are more efficient and stable.
\end{abstract}

\author{
Caroline M. Hoxby \\ Department of Economics \\ Harvard University \\ Cambridge, MA 02138 \\ and NBER \\ choxby@harvard.edu \\ Ilyana Kuziemko \\ Department of Economics \\ Harvard University \\ Cambridge, MA 02138 \\ kuziemko@nber.org
}




\section{Introduction}

School finance is one of the most important public policies in the United States. It can determine whether cities or suburbs grow; it can create or destroy investment in education. School finance programs govern the allocation of approximately 370 billion dollars a year in the United States and 30 billion dollars a year in Texas alone. Despite their importance, these programs are poorly understood by economists. Every good public economist knows the income tax code and how social security works, but he probably knows little about school finance. Even more worrisome is the fact that the creators of school finance formulas often lack economic expertise. They rarely foresee capitalization (the response of property prices to the burdens and rewards created by the formula). Indeed, they sometimes set up systems that maximize property wealth destruction, given the tax revenue collected and the redistribution achieved. Often, they do not foresee that school districts may respond to perverse incentives that the formula creates. For instance, a formula might create incentives for districts to maximize the number of children who are classified as disabled.

In this paper, we show how a school finance program derailed itself. We examine Texas' socalled "Robin Hood" formula, first implemented in 1993-94. Robin Hood is not odd: most other states' systems share its features to some degree. We focus on Robin Hood because it strongly exhibits all of the problems listed above. In less than a decade, the system is approaching collapse: it has exhausted its own capacity. We show that the collapse was predictable: Robin Hood's design maximizes the negative capitalization it causes, shrinking its own tax base. It relies only slightly on relatively efficient (pseudo lump sum) redistibution and heavily on high marginal tax rates.

We wish to state at the outset that we believe that school finance is an important and legitimate problem for state governments. However, it is essentially a tax problem and, like other tax problems, can be solved more or less well. The scale of the mistakes can be massive, simply because school finance operates on a massive scale. We estimate that the Robin Hood plan destroyed about 81 billion dollars of 
property wealth in Texas ( $\$ 27,000$ of property wealth per pupil). To get a sense of the magnitude of this number, suppose that the state had somehow confiscated this wealth, instead of destroying it. The state would have been able to endow a permanent fund that would generate sufficient annual income (about $\$ 1,350$ per pupil) to let every one of its districts spend what the top 5 percent of its districts currently spend.

Our goal is not to criticize all efforts to provide equal educational opportunities, but to use Robin Hood to illustrate some problems of school finance and estimate the effects of school finance parameters. We do not attempt to be prescriptive, but we do refer to more efficient systems than Texas' . ${ }^{1}$ Good intentions about redistribution are not enough in school finance: understanding the economics is important too.

\section{A Brief Primer on American School Finance}

In the United States, education is primarily the responsibility of state governments and local school districts. Districts are the entities that spend money on schools. Their main way to raise revenue by themselves is a proportional tax on the value of local property. ${ }^{2}$ Districts also spend revenue that they receive from their states as aid. ${ }^{3}$ Aid may be negative -that is, a tax on districts' revenues from local property taxes. Roughly speaking, the goal of school finance is to allocate state aid so that districts' choice of the appropriate level of school spending is (up to a point) independent of the permanent income

\footnotetext{
${ }^{1}$ Results from Hoxby (2001) can used to compare different school finance systems. She estimates effects using all 50 states over 30 years.

2 Some districts also get revenue from fees and local sales taxes, but local property taxes account for over 95 percent of districts' revenue. Property tax systems are often slightly progressive because they exempt the first $\$ 10,000$ to $\$ 25,000$ of a house's value (a "homestead exemption") and allow exemptions for the elderly, disabled, veterans, and so on.

3 In addition, districts may receive some federal aid, but it is too small (only 7 percent of public school spending) and too simply categorical (grants for the disabled, limited English proficient, and so on) to concern us here. The major goals of school finance can be achieved only through state school finance, given the allocation of responsibility for schools in the American federalist system.
} 
of the district's own residents and depends only on students' returns to human capital investment and the permanent income of the state's residents. We say "up to a point" because the goals of school finance are articulated in state supreme court opinions, and these opinions nearly always recognize a distinction between school spending that represents human capital investment and spending that represents consumption. School finance need only concern itself with the investment part. ${ }^{4}$ An efficient system of school finance creates minimum deadweight loss, given the progress its makes toward the goal.

People sometimes wonder why school finance is not simply conducted at the state level, with no role for local districts or local property taxes. Many experts in local public finance think that property taxation is uniquely efficient for funding local spending. When used for spending on local schools, property taxes arguably have attributes that make them approximate user fees, which impose minimal deadweight loss and improve local governance. ${ }^{5}$ (The good attributes of property taxes do not apply when they are used to fund a state-level public good, such as investing in the education of poor children in non-local districts.) Thus, it is probably efficient for a system of school finance to start with a fundament of local property taxation and layer state aid on top of it. Nearly every American state has a system with this two-part character. In any case, the funding and allocation of state aid are the key sources of difference between more and less efficient systems of school finance.

\footnotetext{
${ }^{4}$ In other words, the well-off may provide luxuries for their children in school and out of school, and if the distribution of consumption needs to be altered, school finance is not the appropriate mechanism to do it. Income redistribution can most efficiently be done through the income tax and transfer systems, not through state aid to school districts.

5 The essence of Tiebout's insight is that local property taxes are user fees when people are mobile enough for property prices in a jurisdiction to reflect their assessment of the net value of local public goods (such as schools) and local property taxes. Property has two special features as a tax base. It is inherently attached to a particular jurisdiction so it regulates use of the local public good (schools). Its value depends on the assessment of current property buyers and sellers, so that the entire tax base reflects current circumstances even though only a minority of people are mobile at any time. This last feature makes it a semi-automatic mechanism for setting the user fee and regulating the productivity of local good producers. A school district that sets property taxes too high given the actual services it is providing will drive down property prices in the district. Property taxes will fall in an automatic manner until they reach the appropriate user fee. Along the way, district leaders have an incentive to eliminate unproductive programs that were providing too little service for the money spent. A reverse story holds for a program that is unusually productive. See Hoxby (1996) for a formal model and references to the Tiebout literature.
} 


\section{A Useful Analogy}

Before describing a detailed system of school finance, it may be useful to illustrate the issues in the more familiar world of firms. Because we are going to draw an analogy between firms and school districts, suppose that firms cannot pay dividends. ${ }^{6}$

Suppose that government wanted to redistribute income among firms for some reason. A straightforward scheme might take income from firms with high return on capital and transfer it to firms with low return on capital. This system of redistribution would naturally generate some dead weight loss, as firms were discouraged from engaging in business activities that generated returns. However, in its essential character, this tax be like other taxes on income.

Instead of the tax scheme just described, the government might implement a peculiar scheme: it could take income from firms with high market capitalization per unit of book capital and transfer it to firms with low market capitalization per unit of book capital. What would this scheme do? First, like redistribution based on return to capital, the scheme would discourage business activities that generated returns and generate the usual deadweight loss.

The effects would not stop there, however. The present value of a firm's expected tax burden would be capitalized into its share price, so that firms with initially high market capitalization would see their share prices and market capitalization fall. Thus, if the government initially picked a tax rate that would raise the desired revenue given the initial distribution of firms' market capitalization, it would find itself unable to raise that revenue with that tax rate because the tax base would shrink not just as businesses cut back on real activity but in order to capitalize the tax burden itself. (This is an important point: the change in the tax based due to decreased real activity would be small relative to the change produced by capitalization.) The government might raise the tax rate in hopes of getting the level of revenue it initially desired. But, this would merely set off another round of share price changes, as new

\footnotetext{
6 For our analogy, shareholders do benefit from capital gains and firms can repurchase shares.
} 
expectations were capitalized.

At first glance, one might suppose that the negative capitalization among the initially high market capitalization firms would be fully offset by an equal amount of positive capitalization among low market capitalization firms. But, this is very unlikely because the cash would be less valuable in the hands of the recipient firms than it was in the hands of the donor firms. If the cash were equally valuable, the recipient firms would have had it from shareholders in the first place. In short, a redistribution scheme based on market capitalization is unlikely to generate a stable stream of revenue and is likely to generate a series of increases in the tax rate. ${ }^{7}$

A third consequence of the peculiar scheme would be firms' altering their accounting and other practices to maximize the value of book capital relative to true productive capital. The higher a firm's book capital, the lower its tax.

Suppose that the peculiar scheme has a refinement: the government puts the entire tax burden on market-capitalization-per-dollar-of-book-capital above some threshold. This refinement would give some firms negligible incentive to be productive with their marginal investments since these returns would be disproportionately taxed away. Essentially, the refinement raises marginal tax rates, given the average tax rate, thereby heightening distortions.

In summary, the government's peculiar redistribution scheme would not only generate the usual deadweight loss associated with discouraging income-producing business activity, it would also likely be (i) an unstable scheme with rising tax rates, (ii) a scheme that generated rising ratios of book to true productive capital, and (iii) a scheme with high marginal tax rates, given its average tax rates.

7 Of course, if a government understood all of the mechanisms described in this paper and knew all of the relevant elasticities, it could determine whether there was a suitable fixed point: a tax rate at which the desired tax revenue was generated, given the capitalization that the tax rate would cause. The government could then jump to the fixed point. In school finance, this hypothetical situation seems merely to be a pleasing possibility, and not only because governments tend not to foresee capitalization. The Texas data show no sign that a fixed point is being approached. 


\section{Understanding Robin Hood}

The scheme just described sounds so problematic as to be unlikely. Yet, such schemes account for much of the $\$ 370$ billion that is redistributed among school districts each year. The "peculiar scheme" is a strict analogy of Texas' Robin Hood scheme. Most school finance systems in the United States (including Robin Hood) do the equivalent of redistributing on the basis of market capitalization. A good many school finance systems, including Robin Hood, do the equivalent of redistributing based on book values that can be manipulated. Several schemes, including Robin Hood, use systems that maximize marginal tax rates, given their average tax rates.

In reading the description of Robin Hood below, keep the following parallels in mind. A districts' property tax base is analogous to a firm's market capitalization. The relationship between weighted and actual students is analogous to the relationship between book capital and true productive capital. ${ }^{8}$

\section{A. The Origins of Robin Hood}

Texas' Robin Hood formula came about in a fairly typical way. A 1984, a group of school districts sued the state, charging that the then-current system of school finance was unconstitutional. The Supreme Court of Texas found the system to be unconstitutional in 1989, and the Texas legislature then proceeded to enact new systems of school finance. The first two systems took effect in the 1990-91 and 1992-93 school years, respectively, and were also found to be unconstitutional. The third system was Robin Hood. It was implemented in the 1993-1994 school year and found constitutional in 1994. Such back and forth between courts and legislatures is not unusual. ${ }^{9}$

Robin Hood's structure is fairly common. Texas' school finance system is based on local property taxes, on top of which are layered three "tiers" of state aid: a foundation aid system, a

\footnotetext{
8 More accurately, the relationship between weighted students and true student educational needs is analogous to the relationship between book capital and true productive capital.

9 In some states, however, dramatic changes in school finance are made purely through legislature effort, with no court rulings (see Hoxby 2001).
} 
guaranteed revenue system, and a recapture system. All three tiers are based on a district's property value per "weighted pupil." A weighted pupil is not an actual pupil. Students' disabilities, limited English proficiency, need for compensatory education, and other conditions are converted into weights, so that a student may count as multiple students. Hereafter, we use the word "pupil" to refer to an actual pupil, and we use the abbreviation WADA (weighted pupil in average daily attendance) to refer to a weighted pupil. ${ }^{10}$ A district with a high property value per WADA is commonly described as "property-rich;" a district with low property value per WADA is "property-poor."

\section{B. The Recapture System}

In describing Texas' system, it is best to start with the recapture system. ${ }^{11}$ Under this system, a district's property tax base per weighted pupil is divided into two pieces: that below and that above the recapture threshold. The threshold was initially set at $\$ 280,000$ per WADA in 1994 . When a district enacts a property tax rate, the taxes paid on the below-threshold part go into the district's own coffers. The taxes paid on the above-threshold part go into the state's coffers and are then used to fund aid to other districts. The state has "captured" the property tax base above the threshold, although the district continues to be able to set the property tax rate (up to limit, as we shall see).

Figure 1 illustrates the budget constraint and spending choice for a property-rich district that is operating under purely local school finance. It is a standard figure (created by Epple, Filimon, and Romer, 1984), displayed simply to acquaint the reader with its elements. On the horizontal axis in the right-hand quadrant is school spending per pupil $(g)$. On the horizontal axis in the left-hand quadrant is units of fully-taxed property in the district $(H) .{ }^{12}$ On the vertical axis is the price per unit of property

10 We are scrupulous about this distinction. If we use the word "pupil," we refer to an actual pupil.

11 In Texas, the recapture system is formally known as the Chapter 41 system.

12 Typically, the supply of property is assumed to have some elasticity even though jurisdictions' boundaries do not change. The idea is that there is usually some property that is undeveloped or in a low-value use that can be developed as, say, residential property. 
$\left(P_{H}\right)$ and the gross-of-tax cost of a unit of property $\left(P=P_{H}(1+\tau)\right)$. The difference between $P_{H}$ and $P$ is the tax paid per unit of property $\tau P_{H}$-put another way, it is a measure of the loss in non-housing consumption that a person experiences when he pays property taxes. For the purposes of the graph, the property tax rate $\tau$ is defined in such a way that it generates per pupil revenue from tax payments. Note that the property tax rate can be deduced from the figure by examining the ratio of the length of the segment labeled "tax per unit of housing" to the length of the segment from the origin to $P_{H}^{0}$. The line labeled $B C^{0}$ is the district's per-pupil budget constraint, given by the equation:

$$
g=\tau P_{H} H \text { or } P=P_{H}+\frac{g}{H}
$$

The slope of the budget constraint is the marginal tax price of a dollar of per-pupil spending. For graphical exposition, we treat the amount of property consumed under pure local finance $\left(H^{0}\right)$ as one unit. This makes the budget constraint have a 45 degree slope under local finance, which should help to remind us that the marginal tax price of a dollar of per-pupil spending is one under local finance. Finally, note that the scales used in the figure are not realistic: they are designed to allow readers to see the differences among curves.

Figure 1 illustrates an initial equilibrium. The indifference curve of the deterministic voter in the district is tangent to the budget constraint at a point such that the district spends $g^{0}$ per pupil and each household pay taxes of $\tau^{0} P_{H}^{0}$ per unit of housing it consumes. The price of a unit of property, $P_{H}$, generates a supply of housing equal to $H^{0}$; and the gross-of-tax cost of a unit of property, $P$, generates a demand for housing equal to $H^{0}$.

Figure 2 shows what the state projects the property-rich district will do after the recapture system is enacted. State projections assume that property-rich districts do not cut their local spending in response to increases in the marginal tax price, do not cut their consumption of housing in response to an increase in its gross-of-tax cost; and do not see the tax burden capitalized into their property prices. That is, the state projects that property-rich districts will simply raise their tax rate to keep their spending the 
same in the face of recapture and that nothing else will change. In Figure 2, this "hoped-for" response is shown by the budget constraint labeled "BC hoped for" and labeled, hoped-for tax payments to the local district and state. Of course, what the state projects is not an equilibrium. The indifference curve of the deterministic voter is not tangent to $B C^{\text {hoped for }}$ at the initial level of school spending, $g^{0}$, and the supply of housing in the district outstrips the demand, which has fallen because of the higher gross-of-tax cost of housing in the district. Observe that the slope of $B C^{\text {hoped for }}$ will be steeper the higher is the marginal tax price or, equivalently, the larger is the share of property tax wealth that is confiscated. This is because, with recapture, the district pays a dollar of property taxes, but only get to spend a fraction of that dollar, so its marginal tax price is ratio of the district's property wealth per pupil $(v)$ to the recapture threshold per pupil (l). Finally, note that $B C^{\text {hoped for }}$ turns vertical at some point: this is caused by a limit on the property tax rate that was imposed in coordination with the recapture scheme. We will have more to say about the limit later.

Figure 2 has already shown that property prices must fall in the property-rich district: its existing residents want to consume less property than is supplied at current prices. This response is akin to the usual response of consumption when it is taxed. But, property prices will also capitalize the tax burden because of the new equilibrium among districts. That is, people will be deterred from residing in the property-rich district at all, and property prices will fall commensurately. Figure 3 shows how this happens.

Figure 3 shows the pre-recapture and hoped-for tax and spending choices of the property-rich district. It also shows the choices of an intermediate district that is insufficiently property-rich to experience recapture but is also insufficiently property-poor to get state aid. An initial inter-district equilibrium is defined by the existence of an equilibrium within each district (as shown in Figure 1) and "boundary" individuals like the one whose indifference curve is illustrated in Figure 3. Initially, the boundary individual is just indifferent between living in the property-rich district, where he will 
experience more school spending and pay more tax than he would most prefer, and living in the intermediate district, where he will experience lower school spending than pay less tax than he would most prefer. After the recapture scheme is enacted, the boundary individual is no longer indifferent: he strictly prefers the intermediate district. Indeed, the figure is drawn in such a way that the intermediate district is strictly preferred by all of the residents of the property-rich district who preferred school spending less than its former deterministic voter. (To see that the initial deterministic voter would become the new boundary individual if the hoped-for budget constraint prevailed in the property-rich district, mentally extend his top indifference curve - which is tangent to $B C^{\text {hoped for }}-$ and see that it runs right through the choice of the intermediate district.)

The point of Figure 3 is that property prices fall in the property-rich district, not just because property consumption is taxed but also because of capitalization. The result is that the hoped-for budget constraint and choices do not prevail. Instead, there is a new equilibrium like that shown in Figure 4. In Figure 4, the property-rich district has lower property prices, which have re-equilibriated the housing market and limited the outflow of residents to the intermediate district. With lower property prices, the district has less property tax revenue confiscated, faces a lower marginal tax price, and has a budget constraint with a lower intercept and slope $\left(B C^{1}\right)$. At the new equilibrium, the district is spending a little less per-pupil than it did at the initial equilibrium, owing to standard income and substitution effects of a rise in the price of school spending. The dramatic difference is, however, between what the state hoped to collect in tax payments and what it does collect (see labeled lengths in figure). The reason that these amounts are so different is that, under a recapture system, the property wealth that is lost through capitalization affects only the part of district's property tax base that now effectively belongs to the state.

Going forward, keep in mind the shortfall between the state's hoped-for revenue and its actual revenue from the property-rich district.

C. The Foundation Aid System 
Foundation aid systems are easiest to understand them if we think of the state as having converted some local property taxes into a state property tax, which it collects and uses to make a lumpsum grant to each district. The part of the local property tax rate that is converted into a state property tax is known as the foundation tax rate. For instance, in Texas, the foundation tax rate is the first 8.6 mils of each district's property tax rate. ${ }^{13}$ In return for paying 8.6 mils to the state, each district receives a lump sum grant per WADA, called the foundation grant. ${ }^{14} \mathrm{~A}$ foundation aid system can redistribute a good deal of revenue because districts that are property-poor on a weighted pupil basis will contribute far less than they get in grants. In many states, the foundation aid tax rate is set so that the system is selfsupporting: the property-rich districts' payments fund all of the aid to the property-poor districts.

In Texas, the foundation aid system is not self-supporting because the property-rich districts do not participate in it. Districts that would be net contributors to the foundation system are already contributing much of their property tax revenue through the recapture system. In other words, the state cannot take 8.6 mils of their property tax revenue because it has already captured 100 percent of the property tax revenue associated with the base that makes property-rich districts rich. The recapture from a property-rich district is, in practice, larger than the amount it would have contributed under a selfsupporting foundation aid system.

We shall see below that a self-supporting foundation aid system would be substantially more efficient than Texas' peculiar combination of a recapture system and foundation aid system in which property-rich districts do not participate. So, why does Texas use this peculiar combination?

The answer is that lawyers, not economists, designed the system. Texas has a constitutional ban

13 The foundation system is called "Tier 1" in Texas. Property tax rates are usually expressed in mils or thousandths. Thus, a 10 mil rate is a 1 percent tax on property. In Texas, property tax rates are usually expressed as cents per hundred dollars of property value ( 8.6 mils equals 86 cents per hundred). To make the Texas system easy to compare with those of other states, we express everything in mils in this paper.

14 Districts do not actually send checks to the state and then receive checks in return. The state computes the district's net receipt and only that amount is transferred. 
on statewide property taxes, and self-supporting foundation aid system would obviously impose one. Although Texans regularly change their constitution through referenda, lawyers thought they had devised a work-around that would effectively impose a statewide property tax without their having to write supporting legislation. If one looks only at the letter and not the spirit of the law, Texas' recapture system appears to be constitutional because it rests on a bizarre fiction. Legally, a property-rich district does not have to allow its above-threshold revenue to be captured. It is simply the case that, if it refuses to voluntarily contribute this revenue, the state can redraw districts until the property-rich district has property wealth below the threshold. Districts can be redrawn without regard to geographic contiguity so that a poor inner-city neighborhood could, in theory, become part of an affluent suburban district halfway across the state. Similarly, part of an property-rich district could, in theory, be detached and re-attached to a poor district hundreds of miles away. Naturally, to avoid the problems that the redrawing of district boundaries would generate, property-rich districts "voluntarily" contribute revenue. Many people find Texas' pseudo-voluntary scheme confusing, and this is not surprising because it was designed to disguise the effective imposition of a statewide property tax.

Figure 5 shows a property-poor district under purely local finance. Compared to the propertyrich district under local finance (Figure 1), the property-poor district has less pricey property and spends less on schools. Its budget constraint, $B C^{0}$, is such that if the district raises one dollar of property tax revenue, it spends one dollar on its local schools.

Figure 6 shows the property-poor district with a foundation aid system (and a guaranteed revenue system, which we have not yet described). In order to focus on the foundation aid system, notice the length labeled "foundation grant from the state" and connect it visually to the dashed line: this is the budget constraint that would prevail under a foundation system if property prices stayed the same when the system was enacted. The property-poor district's initial budget constraint $\left(B C^{0}\right)$ has its bottom end lopped off because the district's per-property unit contribution to the foundation aid system is given by 
the foundation tax rate $\left(\tau_{F}\right)$ times its property price $\left(P_{H}\right)$. In return, the district receives the foundation grant per pupil $(F)$. Because the foundation grant is larger than what the property-poor district has paid in foundation taxes, the with-foundation-aid budget constraint is shifted out relative to the purely local budget constraint. Nevertheless, over much of its length, the with-foundation-aid budget constraint has the same slope as the no-state-intervention budget constraint. Thus, at least at first glance, foundation aid systems do not distort a district's marginal incentives to spend on schools. (This is not quite true, owing to the fact that a positive foundation grant will raise the demand for housing in the district. However, it is a reasonable first approximation.) By a parallel logic, a property-rich district does not have marginal incentives that are much distorted, under a self-supporting foundation system. In general, foundation systems are closer to being lump sum and have smaller deadweight loss than recapture systems.

\section{The Guaranteed Revenue System}

Like many other states, Texas has a guaranteed revenue system that lies on top of its foundation system. Beyond the 8.6 mils that districts contribute to the foundation system, districts may choose another property tax rate (called the "Tier II rate"). Each mil of a district's Tier II property tax rate is guaranteed to produce at least a certain revenue per weighted pupil, regardless of the district's own property tax base. The state fulfils this guarantee by contributing revenue when a district's own property tax base would generate insufficient revenue. If a district's property tax base generates as much or more revenue than the guaranteed level, it is left alone, neither contributing to nor receiving Tier II aid. (Keep in mind that property-rich districts do not get all the revenue associated with their Tier II rates because the part associated with their above-threshold property wealth is confiscated.)

Under the guaranteed revenue system, a property-poor district might pay only five cents in property taxes for every dollar of revenue it receives. This is such an attractive price for school spending that property-poor districts might be tempted to spend with abandon because nearly all of the money is coming from elsewhere. To prevent such overspending, every guaranteed revenue system has an upper 
limit on the property tax rate for which state will fulfil the guarantee. In Texas, a district's Tier II rate is capped at 6.4 mils and its total property tax rate is capped at 15 mils ( 8.6 mils for the foundation system and up to 6.4 mils for Tier II). Although it is necessary to have a cap on the rate that is guaranteed, an overall cap is unnecessary -most states simply make a district revert to pure local finance once it gets over the guaranteed rate. Texas' overall 15 mil cap is politically motivated. ${ }^{15}$

Figure 6 illustrates how the guaranteed revenue system fits on top of the foundation system. The budget constraint labeled " $B C$ if property prices stay same" shows that the property-poor district first receives its foundation grant and then faces a marginal tax price for school spending that is well below one. Specifically, the slope of the with-guaranteed-revenue budget constraint is given by the ratio of the perWADA revenue guarantee to the district's per-WADA property tax base times one mil:

$$
\frac{r}{\left(\frac{1}{1000}\right) P_{H} H}
$$

(The one mil in the denominator is there because the guarantee is defined on a per mil basis.) The budget constraint turns vertical where the district reaches the property tax rate cap.

Figure 6 illustrates what the state would like to have happen to a poor district getting foundation and guaranteed revenue aid. The district is paying just a bit more property tax than it was paying under purely local finance, yet its schools are spending much more per pupil. The district is getting not only the foundation grant but also guaranteed revenue payments from the state (see labeled length). Figure 6 assumes, however, that the district's property prices do not change when it receives such aid. This is unlikely.

15 Apparently, the 15 mil cap appeals to the property-poor districts because they want to ensure that property-rich districts cannot spend much more than they can. This desire is poorly thought out. Property-poor districts should not try to prevent property-rich districts from spending their own money on inputs that are educationally productive, such as new technology. If the property-poor districts want to make a case for some input being so necessary that it must be included in the foundation grant, they need to have evidence that property-rich districts are uniformly buying it with their own money. 
Figure 7 shows why property prices change. The figures compares the property-poor district with district that is more intermediate (less poor, but still poor enough to receive some state aid). Initially, both districts are in internal equilibrium under local finance, and the indifference of their "boundary" individuals shows that they are also in inter-district equilibrium. With the new state aid programs, there will be a new boundary individual. Looking closely, it will be seen that the new boundary individual has a greater preference for school spending than the old boundary individual (the indifference curve is less flat). Put another way, the property-poor district can now attract an individual with more taste for schooling because the district gets to spend more per pupil. If the property-poor district is more attractive, it must be the case that its property prices rise to re-equilibriate the housing market -that is, to capitalize the benefit it has received.

Actually, the situation is slightly more complicated than this because new residents are not attracted by additional school spending per se; they are attracted by schools that are more valuable. With the property-rich districts, it is reasonable to assume that every dollar of tax payments is converted into a dollar of value in the schools. The assumption is reasonable because local taxpayers are choosing to spend their own money on schools. If their dollar of tax payments is not converted into a dollar of value, they can keep their dollar. Property-poor districts are in a different situation because they pay only a fraction of each additional dollar of school spending. For instance, a district that pays only 10 cents for every dollar of school spending should logically support additional spending so long as the marginal dollar is converted into at least 10 cents of value. Because prospective residents are attracted by schools' value, not their spending per se, property prices in the property-poor district need not rise dollar for dollar with the fiscal benefit conferred by state aid. We should not be surprised to find an asymmetry between the property value lost and gained when a dollar is redistributed. Later, we return to this point in some detail.

Figure 8 shows the property-poor district's equilibrium with state aid, taking into account the rise 
in its property prices. Because its property prices have risen to capitalize the aid, the district makes greater tax payments than the state expected, it gets less guaranteed revenue aid than the state expected, and it spends less on schools than the state expected. However, the differences between the state's expectations and what actually occurs is likely to be rather small. Finally, notice how easy it would be for the district to locate at the kink where the budget constraint $\left(B C^{1}\right)$ turns vertical -even a small change in the slope of the deterministic voter's indifference curve would put the district at the kink. That is, property-poor districts are likely to set their property tax rate at or near the cap, owing to the fact that they pay only a fraction of the marginal dollar.

\section{E. The Weighted Average Daily Attendance (WADA) System}

The parts of the Texas' school finance system described so far are all based on WADA, not actual pupils. There are, of course, many details to the construction of the pupil weights. For the purposes of this paper, however, we can focus on two aspects of the system.

First, districts can face strong incentives to increase their ratio of WADA to actual pupils. By raising WADA/pupils, property-rich districts can reduce their measured wealth, and thereby reduce recapture. Property-poor districts can increase both their foundation and guaranteed revenue aid by raising WADA/pupils. Intermediate districts can increase the probability that they receive foundation or guaranteed revenue aid and decrease the probability that they experience recapture.

Second, although some weights are for conditions that require little or no local judgement (blindness, deafness), other weights are for conditions that do require local judgement. In practice, these are conditions in which there is a spectrum of difficulty, where a low level of difficulty is considered to be part of the normal variation among children and a high level of difficulty is considered to be a disability that requires special treatment: limited English proficiency, speech impairment, learning disability, emotional disturbance. The procedures for classifying students into these disabilities make it 
clear that significant local discretion is used. ${ }^{16}$ In addition, the judgement-sensitive disabilities receive non-trivial weights. One full-time equivalent pupil in speech therapy is 5 WADAs. One full-time equivalent resource room pupil is 3 WADAS (resource rooms are typically assigned to learning disabled students). In Dallas, more than 98 percent of the students who have weights greater than one are students in judgement-sensitive categories. Students in judgement-sensitive categories account for 95 percent of the difference between WADA and pupils. ${ }^{17}$ Cullen (2003) shows that these percentages are typical for Texas.

In short, the easiest way for a district to increase its revenue is to get the maximum out of the WADA system, given the schooling it means to give students. The weights are designed to help cover the costs of the average student who is in a category. Therefore, a district will gain if it can put students into categories where they are marginal candidates for classification. Because classification requires local judgement, it may be quite possible for districts to gain via such accounting practices. Indeed, there are now WADA consultants, whom districts employ to help them get the most out of the system.

WADA accounting may make few people happy. Parents with infra-marginal disabled children may feel that staff devote too much effort to classifying marginal children and too little effort to serving seriously disabled students. Parents with children who are just at the margin of being classified may worry that their child is overclassified and would be better off without a label. Parents with children who have no disability may feel that the school administration is unduly concerned with disability-related paperwork and too little concerned with educating "regular" students.

\footnotetext{
16 See Texas Education Agency, Division of Special Education (2002).

17 Authors' calculations using Summary of Finances, 2003.
} 


\section{Robin Hood in Toto ${ }^{18}$}

Summing up, under the Robin Hood system, property-rich districts are likely to experience falling property prices and contribute less revenue to the system than the state hoped they would. Property-poor districts receive aid, may experience a rise in property prices, and are likely to set their tax rate near or at the cap. Both property-rich and property-poor districts are likely to raise their WADA relative to their number of actual pupils. We have focused on districts at the two extremes because they are most interesting, but of course there are intermediate districts that have intermediate outcomes.

Our summary cannot stop here, however, because the system we have outlined is unlikely to be stable. ${ }^{19}$ Because of capitalization, the state is getting significantly less revenue than it expected, yet it still has to make the promised foundation grants and fulfil its revenue guarantees. The state may be tempted to lower the threshold at which recapture occurs. ${ }^{20}$ The lower threshold will capture more of the property tax revenue of the incumbent property-rich and it will also redefine as property-rich some intermediate districts that previously had too little property wealth to experience recapture. Lowering the recapture threshold sounds like a good solution, but we now know that lowering the threshold will set off another round of capitalization, so that the state will get some extra revenue, but is again likely to be disappointed. Notice, as well, that every time the state lowers the recapture threshold, the property-rich

\footnotetext{
${ }^{18}$ For what it is worth, the following equation summarizes per-pupil spending under the Robin Hood formula:

$$
g \cdot W A D A=\max \left(\tau_{F} \cdot P_{H} \cdot H \cdot W A D A, F \cdot W A D A\right)-\min \left(\tau_{F} \cdot\left(P_{H}-l\right) \cdot H \cdot W A D A, 0\right)+
$$$$
\max \left(\left(\tau-\tau_{F}\right) \cdot P_{H} \cdot H \cdot W A D A,\left(\tau-\tau_{F}\right) \cdot r \cdot 1000 \cdot W A D A\right)-\min \left(\left(\tau-\tau_{F}\right) \cdot\left(P_{H}-l\right) \cdot H \cdot W A D A, 0\right)
$$

The equation above is not particularly elucidating except that, by showing how the systems interact, it demonstrates that neither the foundation aid nor guaranteed revenue systems is at all self-supporting. The recapture system generates revenue that supports the other two systems. People who are familiar with formulas from other states often get confused over this issue.

19 We have previously described the possibility of a "fixed point" tax rate and why states are unlikely to be able to choose one. See footnote 7 .

20 In practice, the state can do this by allowing the threshold to be eroded by inflation.
} 
districts will raise their tax rates. They will gradually but inevitably move toward the property rate cap.

In short, what is the experience of the Robin Hood system likely to be, over several years? From the state's point of view, the system is always disappointingly short of funds and requires greater infusions from the state's general revenue than it expected to need. From the point of view of a resident of a property-rich district, the system is not only burdensome (he loses wealth) but grows more burdensome with each passing year. Moreover, if he has children in schools, he is worried about his district losing all its discretion as it approaches the property rate cap. From the point of view of the resident of an intermediate district, the system probably seemed harmless enough at its inception. But, he may have been surprised to find that, after several years, he has been declared to be property-rich and subjected to recapture. From point of view of a childless (elderly, say) resident of a property-poor district, the system is problematic: although his housing consumption and income are unchanged, he now owes more property tax, mainly because his district has increased its property tax rate but also because his house is worth more. A resident of a property-poor district who has school-aged children probably has the rosiest view: he pays more property tax but his children also attend a school that spends substantially more. Yet, he is likely to be anxious: his district is at or near the property tax rate cap so it has almost no discretion: it depends entirely on the foundation grant and guaranteed revenue level, which are set by the state. The state perennially complains that the system's funding is below expectations and he must fight an ongoing political battle to ensure that the state once again reduces the recapture threshold in its perennial quest for funds. Many parents are likely to be dissatisfied with the WADA system because it may produce decisions that are more oriented toward revenue than toward the proper treatment of disabled and near-disabled children.

Perhaps because of the Robin Hood name or perhaps because property wealth is likely to disappear under Texas' scheme, we are often asked whether Robin Hood is a system of efficient wealth confiscation. Efficient wealth confiscation systems receive high marks from economists because they 
cause few distortions. In them, the state takes assets from the wealthy and either uses them to endow a state fund for ongoing redistribution or redistributes the assets immediately in such a way that the formerly poor have no ongoing need of redistribution. If it is to be efficient, confiscation must be done in a fell swoop so that it becomes a sunk cost for formerly wealthy, who get on with their lives and do not distort their ongoing behavior. Robin Hood has none of this character. We will see that the state imposes high marginal tax rates on school spending and wealth, returns repeatedly to tax wealth this period that it left untaxed last period, and cannot show, for its efforts, either an endowment nor a set of formerly poor districts that now have the wealth to manage school spending on their own. ${ }^{21}$

In short, after several years, a system like Robin Hood is unlikely to enjoy the widespread popularity enjoyed by the man after whom it is named. Many people will feel that property taxes are rising too fast; school superintendents and parents are likely to feel unduly constrained; state legislators are likely to be tired of the perennial problems. Indeed, to the best of our knowledge, Texas is the only state that has been sued over its school finance system by property-rich and property-poor districts at the same time.

A curious feature of the Texas Supreme Court opinion in favor of the Robin Hood system is that the Court stated that if all districts were to reach the 15 cap, it would be obvious that they had no discretion and that the 15 mil tax was a statewide tax. ${ }^{22}$ The Court's statement created a widelyrecognized automatic trigger for the system's demise. Currently, more than 80 percent of Texas pupils

${ }^{21}$ Some states, including Texas, actually do have endowments that support school aid. Typically, these were created in the early days of the state from sales of government land. Because they were set up long ago, when real per-pupil spending and state populations were smaller, most endowments are insufficiently large to fund significant aid today. However, they demonstrate that endowments can be practical.

22 This is a curious standard from an economist's point of view because it is evident that the combination of the foundation aid system and recapture system already constitute a statewide property tax (mentally assign the first 8.6 mils of recaptured revenue to the foundation aid system and there you are). Nevertheless, this is the standard set by the Court. 
are in districts within half a mil of the cap. ${ }^{23}$ The system is about to become unconstitutional and few people seem motivated to resuscitate it in anything like its current form.

\section{An Empirical Strategy for Testing Hypotheses about Robin Hood}

We hypothesize that:

(i) All else equal, capitalization of Robin Hood drove down property prices in recapture districts.

(ii) Owing to capitalization, the revenues contributed by property-rich districts to the Robin Hood system were insufficient to fund the intended aid. As a result, the state reduced the recapture threshold in real terms.

(iii) As a result of the recapture threshold falling in real terms, an increasing number of districts were subjected to recapture.

(iv) As a result of capitalization, districts that faced recapture could not keep up with the demand for school spending without raising their property tax rates. Such districts were gradually pushed toward the 15 mil cap on property taxes.

(v) Low marginal tax prices induced property-poor districts to set their property tax rates at or near the cap.

(vi) Districts will have increased their WADA/ADA ratio depending on their financial incentives to do so (where they are in the school finance system).

A. Parameters that Describe the School Finance System

Systems of school finance can be described by a few parameters that characterize the budget constraints illustrated in Figures 1 through 8:

(i) a district's marginal tax price $\left(M T P_{i j t}\right)$-that is, the slope of its budget constraint;

(ii) a district's virtual grant ( virtual grant $_{i j t}$ ) -that is, the difference between the intercept of pure local

\footnotetext{
23 The source is Texas Education Agency, Summary of Finances 2003-04.
} 
finance budget constraint and the intercept of the projection of the with-aid budget constraint; ${ }^{24}$

(iii) the property tax rate cap;

(iv) the effect of a change in WADA/pupil on a district's revenue;

(v) the share of the change in property tax revenue that a district keeps when its property values change and affect its local revenue ( $s$ hare $k e p t_{i j t}$ ).

The first four parameters listed above are self-evident. The fifth parameter, however, requires a little explanation. Share kept $_{i j t}$ affects the inter-district equilibrium illustrated in Figures 3 and 7. Essentially, when a school finance reform makes households shift from one district to another, they change house prices which change local property tax revenues which change districts' budgets according to share kept $_{i j t}$. Because districts' budgets affect households' demand to live in them, share kept $t_{i j t}$ is important for establishing how far property prices move.

An additional virtue of share kept $_{i j t}$ is that it indicates the power of the incentives facing a district's staff. Suppose staff make extra efforts that raise property values and, consequently, local property tax revenues in their district. The larger is the share of these extra dollars that their district keeps, the more likely is their schools' budget to rise. If staff like larger budgets, then their incentives are

${ }^{24}$ Figure 8 has nice geometry that shows that the virtual grant is equal to net foundation aid for a district that receives foundation aid only (no guaranteed revenue aid). Project the dashed budget constraint (the one at a 45 degree angle) to the horizontal dotted line labeled $P_{H}^{1}$. The length of the $P_{H}^{1}$ line that remains is the intercept or virtual grant. Its length is given by the foundation grant minus one side of the right triangle created by the projection of the dashed line. The length of that triangle's side is exactly equal to the vertical distance between the $P_{H}^{1}$ line and the horizontal part of $B C^{\mathbf{1}}$. That vertical distance is what the district pays into the foundation aid system. Subtract the district's payments into the foundation aid system from its foundation grant to obtain the virtual grant.

For a district that receives guaranteed revenue aid, the virtual grant is not merely net foundation aid because its budget constraint is not at a 45 degree angle. Project the sloped part of $B C^{1}$ onto the $P_{H}^{1}$ line, making a right-angle triangle. The short vertical side of this triangle has length equal to the district's payment into the foundation program. The long horizontal side of the triangle has length equal to: (district's payment into the foundation program) * (guaranteed level per cent of property tax rate)/(amount district raises per cent of property tax rate). The virtual grant is the foundation grant minus the length of the long horizontal side of the triangle. 
higher powered when share kept $_{i j t}$ is higher. ${ }^{25}$

\section{B. Our Empirical Strategy}

Our empirical strategy is straightforward because, at heart, we are analyzing one big policy change in school finance. Of course, the Robin Hood formula affected different districts differently, but the differences are not random but related to districts' initial characteristics. Therefore, it is best to think of the timing of Robin Hood as the main source of exogenous variation: we will look for districts to deviate from their prior behavior with timing that makes it appear that they are reacting to Robin Hood. Because we want the Robin Hood parameters that a district faces to reflect only the impact of the law, not the district's endogenous response to it, we use simulated parameters. That is, for each year, we take observations on each district before Robin Hood, use them to predict what property values would have been in the absence of Robin Hood, and run the predicted value through the contemporary school finance laws to determine what marginal tax price, foundation tax, et cetera would have been with Robin Hood but no other change. We use the simulated parameters as instrumental variables, instrumenting for each actual parameter with the simulated parameter that the district would face if the law had changed but its own behavior had not. This now-standard technique is usually called simulated instrumental variables estimation. Simulated parameters are powerful instruments and valid (if they are valid) by construction. That is, a reader who knows how they are constructed should be able to judge their validity. We also estimate reduced-form equations, which generate "intention-to-treat" estimates of the Robin Hood system. $^{26}$

${ }^{25}$ Of course, if district staff maximize property values, then share kept $_{i j t}$ is a measure of the power of their incentives. Districts' maximizing property values is a popular assumption among local public economists, but it is presumably just a convenient shorthand for the ways in which staff benefit from higher property values. No one claims that they literally have contracts that depend on their raising property values.

${ }^{26} \mathrm{We}$ are concerned about differentiating between changes in the parameters that are exogenous (caused purely by the law change) and endogenous to the districts' reactions to the law changes. We address this problem using simulated instrumental variables, which do not share some of the features of typical instrumental variables. For instance, with simulated instruments, it is obvious where the variation in the instruments comes from: the law change. Also, the case for the instruments fulfilling the second instrumental variables condition (lack of correlation 
Because we predict that some responses will play out over time, we graphically show districts' responses for the years after the law change, up to the 2001-02 school year. We treat several variables as simultaneously determined dependent variables: property prices, property tax rates, school spending, and the WADA/pupil ratio. We also show how the recapture threshold evolved from the beginning of Robin Hood to the present.

\section{Obstacles for Our Empirical Strategy}

As in most studies of tax reforms, the primary empirical obstacle is determining what would have happened in the absence of the reform. That is, what is the correct counterfactual? This issue is much discussed in studies of income tax reforms, but less discussed for school finance. ${ }^{27}$

Overall, we believe that constructing a counterfactual is less problematic for Texas school finance than it is for an analysis of an income tax reform. First, the timing of the reform was more arbitrary than is a typical income tax reform. Income tax reforms typically begin in a legislature that is sensitive to the business cycle, but the timing of school finance reforms is dictated by an erratic interaction of plaintiffs, courts, and legislatures. Even if the initiation of the Edgewood case (1984) were endogenous to the business cycle, the school finance system was not affected at all until 1989-90 and Robin Hood was not implemented until 1993-94. Second, in tax reform analysis, it is often difficult to follow individuals. We do not have this problem: a district is a district and the data form a complete panel. Third, unlike individuals who have many idiosyncracies in their lives that are unobserved by the econometrician, a district's menu of choices and its actions are entirely public. As a result, the estimates we use for making predictions are precise. Fourth, there were no other major school or tax reforms in

between the instruments and unobserved determinants of the dependent variable) is straightforward: the instruments are constructed to fulfil this condition as much as possible. Because each simulated parameter has exactly the same structure as the parameter it mimics, the reduced form equation produces "intention to treat" estimates of Robin Hood, while the simulated instrumental variables estimates are "treatment on the treated" effects of Robin Hood.

27 See, for instance, Feldstein (1995) on the importance of using panel data and Goolsbee (2000) on the difficulty in constructing a counterfactual for high income people. Gordon (forthcoming) discusses this issue when constructing a counterfactual for a major change in federal Title I spending on schools. 
Texas over the same period that are likely to confound our results. ${ }^{28}$

\section{Constructing a Counterfactual}

We need to construct a counterfactual both in order to construct the simulated parameters and in order to control for what would likely have happened in Robin Hood's absence.

We use data from 1980 to 1990 to estimate how each district's property tax base is affected by natural gas and oil prices; personal income in its metropolitan area (or county, for non-metropolitan districts); employment by industry in its metropolitan area (county); population in its metropolitan area (county); state-level employment in the oil, gas and mining industry; and gross state product. We estimate a district-level regression with most variables at the county or metropolitan area level in order to ensure that the covariates are strong predictors of property values but also plausibly exogenous to the conduct of the individual school district. ${ }^{29}$ In order to allow property prices to vary more with oil and natural gas prices in districts that depend heavily on that industry, we interact the oil and gas prices with indicators for a district's decile when districts are categorized by the percentage of their property in oil and gas land. We also interact oil and gas prices with indicators for a district's quartile when districts are categorized by the percentage of their employment in the oil and gas industry. ${ }^{30}$ In order to allow

28 Texas implemented an accountability program for schools in the $1990 \mathrm{~s}$, but the financial consequences of the program were negligible, given the scale of revenues and spending that we examine.

Texas increased aid for building school facilities in property poor districts in 1997 and for all districts in 2001. We therefore look at the property tax and school spending that is not for facilities, but is for "maintenance and operations." Maintenance and operations taxes and spending are more than 95 percent of the total in Texas.

Texas raised the homestead exemption from $\$ 5,000$ to $\$ 10,000$ in 1998 . Using the comptroller's data on what assessed property values would have been with and without exemptions, we eliminate the confounding impact of the exemptions from our data.

29 In other words, we deliberately do not use a district's own values for most variables. This is because it is plausible that a metropolitan area's socioeconomics and demographics change in a way that is exogenous to a district's own conduct and circumstances, but it is not plausible that a district's socioeconomics and demographics are exogenous to its conduct and circumstances (especially the impact of Robin Hood itself). We have performed all of the analysis using only state level variables (as opposed to metropolitan and county) and get similar but less precise predictions, as we would expect.

30 To get these percentages, we used 1987, a year in which the average price of a barrel of oil was typical for the 1980s: \$18.1. 
property prices to vary more with personal income in districts that depend on residential property values, we interact metropolitan (county) per capita personal income with indicators for a district's decile when districts are categorized by the percentage of their property that is residential. Finally, because income growth in the 1980s and 1990s was not experienced equally by low wage and high wage earners, we interact metropolitan (county) per capita personal income with indicators for a district's quartile when districts are categorized by their initial median household income.

Specifically, our equation is:

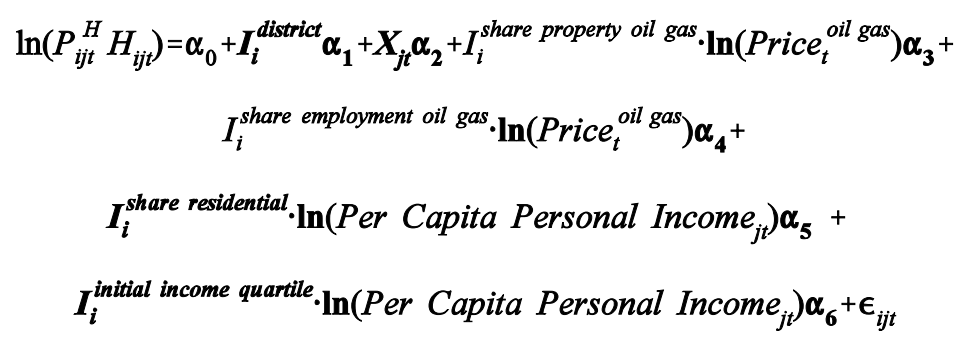

where $i$ indexes districts, $j$ indexes the metropolitan area or county, $t$ indexes time, and the vector $\boldsymbol{X}_{j t}$ is the set of metropolitan-, county-, and state-level variables described above. Notice that equation (1) includes a fixed effect for each district and has a log-log specification. The equation explains the data from the 1980s extremely well: the F-statistic is 74.2 for the test of the hypothesis that the coefficients on the explanatory variables, not including the district fixed effects, are jointly equal to zero. With the district fixed effects, the equation explains 99.4 percent of the variation. We believe that the resulting predictions for the 1990s are reliable because most of the variation in property values in Texas is driven by household incomes or by oil and gas prices, which affect property values in systematic ways. ${ }^{31}$

31 The elasticity of property values to oil prices rises with a district's dependence on oil and gas land and is equal to 0.10 for the top decile of dependence. The elasticity of property values to natural gas prices rises with a district's dependence on oil and gas land and is equal to 0.24 for the top decile of dependence. The elasticity of property values to metropolitan (county) per capita personal income is 0.07 for districts with initial median household income in the bottom quartile, 0.13 for districts in the second quartile, 0.17 for districts in the third quartile, and 0.03 for districts with initial median household income in the top quartile. A full set of coefficients is available from the authors, but these are the most interesting ones.

Texas assessors value oil and gas land using a discounting method, published oil and gas price forecasts (which tend strongly to reflect current prices), and information about which wells would be economic at which price. For a given parcel of oil or gas land, nearly all of the year-to-year variation is driven by current oil and natural gas 
In order to predict district's number of pupils, we regress pupils on district indicators, metropolitan (county) population, and employment by industry. ${ }^{32}$ We use 1980 s data and a log-log specification. Not surprisingly, population and employment strongly predict pupils: the F-statistic is 109.5 for the test of the hypothesis that the coefficients on the explanatory variables, not including the district fixed effects, are jointly equal to zero. With the district fixed effects, the equation explains 99.8 percent of the variation. We then apply each district's initial WADA/pupil ratio to its predicted number of pupils to get a predicted WADA for each district. ${ }^{33}$

\section{E. The Estimating Equations}

We estimate the effects of Robin Hood's parameters using straightforward regressions of districts' property values and spending on the parameters listed above, district indicators, and districts' predicted property values (which summarize all of the other influences on property values). We use a $\log -\log$ specification, except that we do not log share $k e p t_{i j t}$ because it is a share. ${ }^{34}$ The estimating equations for property values and school spending are:

$$
\begin{aligned}
& \ln \left(P_{i j t}^{H} H_{i j t}\right)=\beta_{0}+\beta_{1} \ln \left(M T P_{i j t}\right) \cdot I_{i j t}^{M T P \geq 1}+\beta_{2} \ln \left(M T P_{i j t}\right) \cdot I_{i j t}^{M T P<1}+\beta_{3} \ln \left(\text { virtual grant } t_{i j t}\right)+ \\
& \beta_{4} \text { share kept }_{i j t}+\beta_{5} \bigwedge_{\ln \left(P_{i j t}^{H} H_{i j i t}\right)}+\boldsymbol{I}_{i}^{\text {district }} \beta_{6}+\xi_{i j t} \\
& \ln \left(\text { pps }_{i j t}\right)=\delta_{0}+\delta_{1} \ln \left(M T P_{i j j}\right) \cdot I_{i j t}^{M T P \geq 1}+\delta_{2} \ln \left(M T P_{i j t}\right) \cdot I_{i j t}^{M T P<1}+\delta_{3} \ln \left(\text { virtual grant }_{i j t}\right)+ \\
& \delta_{4} \text { share kept }_{i j t}+\boldsymbol{\delta}_{5} \bigwedge_{\ln \left(P_{i j t}^{H} H_{i j t}\right)}+\boldsymbol{I}_{i}^{d i s t r i c t} \boldsymbol{\delta}_{6}+\xi_{i j t}
\end{aligned}
$$

prices. It is important to associate oil and gas prices with the correct year of property valuation because there is a lag between actual price changes and their use by assessors.

$32 \mathrm{We}$ found that employment in agriculture and low-skill industries were less noisy indicators of recent immigrants than was survey data on immigrants by metropolitan area (county) or data on legal immigrants' intended destination.

33 We hold constant each district's ratio of WADA/pupils at its 1991 value because this was the first year in each WADA was measured and districts would have had little time to react to the law by reclassifying students.

34 We use a log-log specification because it is implied by common specifications for demand for school spending, such as those derived from Cobb-Douglas utility. As a check, however, we estimated a levels specification. It generated comparable estimates but fit the data less well. 


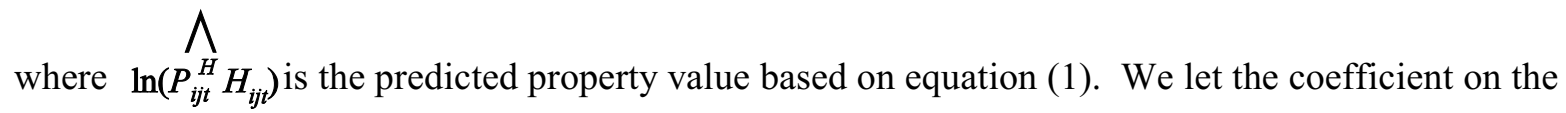
marginal tax price depend on whether a district's revenues are being confiscated $(M T P>1)$ or matched $(M T P<1)$ by the state. We expect the coefficients on both $M T P$ interactions to be negative, but, for the reasons we noted above, we expect the coefficient to be larger in absolute value if revenues are being confiscated. $^{35}$ We expect positive coefficients on the virtual grants. In the property value equation, we expect a positive coefficient on share kept $_{i j t}$ because, intuitively, it indicates the return to investments that raise property value. We do not, however, have a clear prediction for the sign on share kept $_{i j t}$ in the spending equation. A low value of share kept $t_{i j t}$ insulates a district's spending from variation in its property values, but the effect of such insulation on a district's level of spending is not obvious.

Below, we will see that simple figures establish the basic consequences of Robin Hood. What, then, is the additional value of regression analysis? Regression estimates reveal detail in a way that figures cannot. Moreover, they generally show the trade-offs inherent in school finance systems and could be used to predict the effects of other states' schemes. Although we do not claim to estimate a fully structural model, the parameters that describe the budget constraints imposed by Robin Hood are derived from theory, our measures of them are very accurate, and our specifications are reasonable if the demand for school spending has a Cobb-Douglas or similar form. Our simulated instrumental variables estimates represent treatment-on-the-treated effects of the parameters. Our reduced-form estimates are also useful. If another state were to design a school finance plan under the naive belief that no capitalization would occur, we would get the most accurate predictions of the plan's effect if we combined our reduced-form estimates with the state's naive projections of its plans' parameters.

${ }^{35}$ In fact, we tested the hypothesis that the coefficients on the two $M T P$ interactions were the same and rejected it at the 0.0001 level. 


\section{Data}

All of our data are either administrative or census data. Most data are from the Texas Education Agency's Summary of Finances files (Texas Education Agency, Division of State Funding, 2003). These are the data used to generate each district's actual aid. The files contain the information we use on assessed property values, pupils, WADA, property tax rates, foundation grants, recapture, and so on. In addition, we use districts expenditure data from the Academic Excellence Indicator System files (Texas Education Agency, Division of Performance Reporting, 2004). We use data from the Texas Comptroller's annual Property Value Study to determine whether assessed and market property values correspond (Texas Comptroller of Public Accounts, various years) ${ }^{36}$ Finally, we make minor use of census data and energy price data: United States Department of Commerce (1983, 2003, 2003, 2004), United States Department of Education (1994), United States Department of Energy (2003).

On the whole, data are not an issue in this study. The administrative data are comprehensive, and errors in the data are unlikely because they would have been costly to some party. In any case, because we are using the actual data that were used to generate aid, it is likely that the state and districts would have responded to erroneous data as though they were correct.

\section{Districts' Budget Constraints: Before and After Robin Hood}

In this section, we show the before-after differences in Texas' school finance parameters for two exemplary districts and districts categorized by their property-richness. Texas has 1031 conventional school districts - too many to show individually. The ideal "before" year is the 1988-89 school year because it precedes any attempt by the state to respond to the Edgewood case. It does not matter much

\footnotetext{
36 We also have data on a very large sample of individual house sale transactions covering the late 1980s through today. So far, we have merely used the data to confirm that assessed values reflect market values. We could also use the data to see whether house consumption reacts in predictable ways. Are people less likely to build onto a house in a district that faces recapture, for instance?
} 
whether we choose 1994-95, 1995-96, 1996-97, or 1997-98 as an "after" year. In the years between 1988 and 1994, the structure of the foundation grant and guaranteed revenue system were in place, but the level of aid was considerably lower than they were after recapture began. ${ }^{37}$

First consider Edgewood Independent School District and Alamo Heights Independent School District in Bexar County. They are geographically neighboring districts. The former was property-poor (bottom 5 percent of property wealth per pupil) and the latter was property-rich (top 5 percent of property wealth per pupil). In 1989, as shown in the top panel of Table 1, Alamo Heights families had a significantly higher median income $(\$ 53,078)$ than Edgewood families $(\$ 22,945){ }^{38}$ In 1988-99, Alamo Heights had a property tax rate of 12.4 mils, and Edgewood had a property tax rate of 9.8 mils. By 1997 , both districts' property tax rates had hit the cap of 15 mils. 15 mils may not sound like a high tax rate, but this is because it is expressed as a share of an asset price. It we convert it into a tax on annualized property services, we can compare its magnitude to that of other taxes. A 15 mil tax on property is approximately a 19 percent tax on annualized housing services. ${ }^{39}$ A 19 percent tax rate is not low relative to taxes on other goods and services.

Now examine the bottom panel of Table 1, which shows school finance parameters for Edgewood and Alamo Heights, with both the intended "after Robin Hood" parameters and the ones that actually evolved. Any differences between the intended and actual parameters are due to capitalization.

37 During the 1992-93 and 1993-94 school years, a peculiar formula was used that was quickly found unconstitutional. The formula involved grouping Texas school districts in County Education Districts and redistributing some funds within the groups. From our point of view, this formula is an unnecessary detour between the old formula and the Robin Hood formula. Robin Hood is an adaptation of the old formula, not the County Education District formula, which was wholly discarded after its short "life." Because the County Education District formula was found to be unconstitutional quite quickly, it would not have changed expectations much or generated much capitalization.

38 In this and the following paragraphs, money amounts are in 2002 dollars, adjusted using Bureau of Labor Statistics, Consumer Price Index.

39 See Calabreze and Epple (2004) for an explanation of why 0.08 is a reasonable factor for converting property values into annualized property services. 
Edgewood's marginal tax price fell from 1 in 1988-89 to 0.11 in 1997-98 (that is, the district only paid 11 cents on the dollar for marginal spending). Its intended and actual marginal tax price were the same in 1997-98, implying that little capitalization occurred (a fact we demonstrate shortly). The lump sum transfer to Edgewood was \$3,187 before Robin Hood and about \$3,732 after Robin Hood (intended and actual are similar). Notice that Robin Hood raised Edgewood's lump sum transfer by a relatively small amount (17 percent), but reduced Edgewood's marginal tax price ninefold. The share kept $_{i j t}$ variable shows that, even before Robin Hood, Edgewood's staff could not raise their school budget much if their efforts raised property values in the district. For every dollar of extra tax revenue generated by higher property values, Edgewood kept 33 cents. ${ }^{40}$ After Robin Hood, Edgewood kept zero cents of extra tax revenue generated by higher property values.

Before Robin Hood, Alamo Heights had an marginal tax price of 1, meaning that it paid a dollar in taxes to spend a dollar. If no capitalization had occurred, Robin Hood would have raised Alamo Heights's marginal tax price to 2.56. Because of substantial negative capitalization (a fact we demonstrate shortly), its marginal tax price increased to 1.39 (the district paid $\$ 1.39$ in taxes to spend a dollar). Alamo Heights got no lump sum transfer before Robin Hood, but in 1997-98 it could maintain its pre-Robin Hood per-pupil spending only by putting $\$ 3,573$ per student into the state's recapture system. If capitalization had not occurred, much more $(\$ 15,041$ per student) would have been confiscated. Finally, before Robin Hood, Alamo Heights staff could raise their schools' budget by a dollar that if their efforts raised an extra dollar of tax revenue through higher property values. After Robin Hood, Alamo Heights kept zero cents of every extra tax dollar from changing property values. Having looked at two specific districts, we now show, in Table 2, parameters of the school

\footnotetext{
40 Of course, the reverse was equally true. If the staff engaged in some activity that caused property values and thus property tax revenues to fall, the district only experienced 33 cents on the dollar of the consequences.
} 
finance system for 20 property-wealth-per-WADA quantiles. ${ }^{41}$ We show only the actual "after Robin Hood" parameters. We do not show the intended parameters simply because they would force us to discuss capitalization prematurely: we prefer to show the facts on capitalization first. The most noteworthy changes in budget constraints occur at the two ends of the property wealth spectrum. The property-poorest quantiles experience very large negative changes in their marginal tax prices and relatively small positive changes in their lump sum transfers. The property-richest quantiles experience positive changes in their marginal tax prices and substantial recapture. In short, Edgewood and Alamo Heights are fairly typical of the bottom and top quantiles, respectively.

Table 3 shows how the recapture threshold fell over time in real terms, from about $\$ 340,000$ in 1994 to $\$ 305,000$ in 2002. Because the threshold fell, more districts were swept into the recapture group. In 1994, recapture districts accounted for only 5.1 percent of students. By 2002, 10.3 percent of students were enrolled in recapture districts. Moreover, the predicted enrollment numbers suggest that 22.3 percent of all Texas students would now be in recapture districts if they had not been deterred from living in them by the Robin Hood scheme. Table 3 demonstrates that Texas has been changing the parameters of the system in an apparent effort to fill a perennial shortage of revenue. Below, we show that capitalization did likely cause such a revenue shortage.

\section{Robin Hood and Capitalization}

We now turn to the capitalization consequences of Robin Hood, using figures to illustrate the evidence before presenting regression results.

\section{A. Capitalization of Robin Hood into Property Values: A Graphical View}

Figures 9 through 11 show the predicted and actual property tax bases for the property-poorest

41 The quantiles and statistics in Table 2 are pupil-weighted. That is, each of the 20 quantiles contains approximately five percent of the Texas pupil population. Quantiles 15 and 16 cannot be separated because Houston, a district with very large enrollment, straddles them. 
districts (quantile 1), intermediate (quantile 10), and property-richest (quantile 20) districts in Texas. Observe that the three figures all have the same scale: the vertical distance on the figures represents $\$ 300,000$ per pupil. Figure 9 shows that, in the property-poorest districts, the actual property tax base roughly kept pace with the predicted base, suggesting that little or no capitalization occurred. Figure 10 shows that intermediate districts like those in quantile 10 experienced a small amount of negative capitalization -about $\$ 12,500$ per pupil- after Robin Hood. The negative capitalization begins in about 1990 and grows through 1994, after which the negative capitalization holds steady. This time pattern makes sense because school finance laws began affecting intermediate districts in 1989 and had increasing effects on them through 1994, when Robin Hood was enacted and the law became stable so far as they were concerned. Note that the appearance of negative capitalization does not depend on our having generated an overly optimistic forecast: their actual property value per pupil fell. Keep in mind that this decline occurred during a decade of robust economic growth in Texas and the United States.

Figure 11 shows that property-rich districts like those in quantile 20 experienced very substantial negative capitalization, beginning in 1993-94 and growing thereafter, with no signs of slowing down. This timing makes sense. Recapture began in 1993-94, although Robin Hood was not declared constitutional until 1994. The real recapture threshold fell in nearly every subsequent year, raising the recapture burden for districts already in the recapture system and sweeping new districts into the recapture system. Admittedly, some of the appearance of negative capitalization in Figure 11 depends on our prediction that property values should have risen over the 1990s, but it is well known that the 1990s were a period of unusually rapid income growth for the wealthy. The median income of households in the top quantile districts grew by 20 percent between the 1990 and 2000 Censuses of Population. ${ }^{42}$

\footnotetext{
42 Authors' calculations based on United States Department of Education, 1994 and United States Department of Commerce, School District Demographics, 2003.
} 
Moreover, oil and natural gas prices rose substantially in the late $1990 \mathrm{~s}^{43}$ Nevertheless, Figure 11 shows that actual property value per pupil fell in nominal dollars in quantile 20 districts. Even if one thought that our prediction of property values in quantile 20 districts is overly optimistic (and we do not think that it is, given that it is growing no faster than household income and more slowly than oil and gas prices), it would be hard not to conclude that Robin Hood had caused substantial negative capitalization. Readers may be interested to note that Figures 9 through 11 would look much the same if we had shown aggregate property values, rather than aggregate property values per pupil. ${ }^{44}$ In other words, it is changes in property values, not changes in pupils, that dictate the shape of each line.

\section{B. Capitalization of Robin Hood into Property Values: Regression Analysis}

Table 4 shows how Robin Hood's parameters generated capitalization, displaying the coefficients of interest from equation (2). ${ }^{45}$ Before examining the coefficients of interest, however, observe that they explain the data very well. Figures 12 and 13 repeats the comparison of actual and predicted property values without Robin Hood that we previously showed in Figures 9 through 11. We also add lines showing the predicted property values with Robin Hood. Figures 12 and 13 are produced using, respectively, the simulated instrumental variables and reduced-form estimates in Table 4. Even in quantile 20, which has dramatic changes in capitalization, the estimates do a good job of explaining why actual property values diverged from the path they were predicted to take in the absence of Robin Hood.

Table 4 shows that, in property-rich districts that experience an increase in their marginal tax prices, property values fall by 24.8 percent for every doubling of marginal tax prices. For instance, the

43 Oil prices were rather steady through 1995, but had risen by more than 30 percent by 2001 . Natural gas prices were steady through 1998, but had nearly doubled by 2001 . See United States Department of Energy.

44 These figures are available from the authors.

45 For reasons of space, we do not show individual districts' fixed effects or the coefficient on the predicted property tax base, which (by construction) functions as a sufficient statistic for factors that systemically affect a district's tax base and generates a coefficient very close to one. Indeed, we can restrict it to be equal to one and the other coefficients hardly change. 
marginal tax prices of districts in quantile 20 rose from 1 to 1.75 ( 0.56 natural log points), implying a decline in property values of about 13.9 percent from this parameter's effect. The next coefficient suggests that, in property-poor districts that experience a decrease in their marginal tax prices, property values rise by 5.36 percent for every halving of their marginal tax prices. The typical property-poor (quantile 1) district saw its marginal tax price fall from 1 to 0.14 (1.97 natural log points), implying a rise in property values of 11.8 percent. The coefficient on the virtual lump sum grant suggests that doubling it would raise property values by only 0.6 percent. While a small capitalization effect of foundation grants is consistent with evidence in Hoxby (2001), it must also be admitted that Robin Hood generated such modest variation in foundation grants that it is not a good application for estimating their effects. ${ }^{46}$ The coefficient on share kept $_{i j t}$ is 0.1489 . Share kept $_{i j t}$ fell by 0.33 for property-poor districts in quantile 1, implying a 5 percent decrease in property values. It fell by 0.67 for property-rich districts in quantile 20, implying a 10 percent decrease in property values.

Comparing the columns of Table 4, we see that the reduced-form estimates are generally attenuated versions of the simulated instrumented variables estimates. This is exactly what we expect. The intention-to-treat estimates suggest that parameters are less efficacious because they include the fact that capitalization waters down the intended effect of the school finance scheme.

Summing up, we expect property-rich (quantile 20) districts' property values to have fallen by 24 percent (about $\$ 246,000$ per pupil), expect the property-poorest (quantile 1) districts' property values to rise by about 6.8 percent (about $\$ 4,700$ per pupil), and expect intermediate outcomes for intermediate districts. For instance, we expect a 4.6 percent decline in property values for quantile 10 districts (about $\$ 12,600$ per pupil). Considering that the estimates are for an average "after Robin Hood" year, while the

\footnotetext{
46 That is, we need variation in the virtual lump sum grants that driven by changes in foundation grants, not driven by changes in the slope of the budget constraints shown in Figures 1 through 8 . Changes in the slope are changes associated with marginal tax prices, and we need to have variation in the virtual grants that is independent of variation in marginal tax prices if we are to distinguish the roles of the parameters.
} 
figures show changing dynamics, the estimates very correspond well to the graphs, except that Figure 9 evidently masks a small amount of positive capitalization in the property-poorest districts. ${ }^{47}$

Aggregating over all districts' gains and losses in property values, our estimates suggest that Robin Hood caused Texas to lose a net of $\$ 27,000$ per pupil in property wealth. The best estimate would actually vary by year and is between $\$ 20,728$ and $\$ 33,495$ in property wealth per pupil, with later years generally associated with higher losses.

\section{Understanding the Capitalization that Occurred}

We have seen that negative capitalization of approximately $\$ 290,000$ per pupil apparently occurred in quantile 20 districts. This may seem like a large number, but recall the numbers for Alamo Heights to see that it is reasonable, given the intended recapture. Robin Hood intended that Alamo Heights should pay $\$ 15,041$ per student every year. If the district were to endow permanent $\$ 15,041$ scholarships, it would cost the district at least $\$ 300,000$ per pupil. ${ }^{48}$ Robin Hood essentially attached the obligation to fund just such scholarships to every property in Alamo Heights. Thus, we should not be surprised to find that properties which were worth \$X per pupil before Robin Hood were worth about \$X-290,000 after it.

Such losses of property wealth had serious consequences for the stability of Robin Hood because quantile 20 districts were disproportionately responsible for putting dollars into the state aid system. It is no wonder that, with their property tax bases falling in response to Robin Hood, the state would find itself perennially disappointed about the revenue captured from these districts.

We are not surprised by substantial negative capitalization of Robin Hood in property-rich districts, but why is there so little positive capitalization in property-poor districts that Texas had a net

\footnotetext{
${ }^{47}$ In particular, the property-rich districts have lost about $\$ 246,000$ per pupil in an average "after" year but about $\$ 290,000$ per pupil by the last "after" year we show.

48 If the payout rate were five percent real or about eight percent nominal, the amount would be $\$ 300,820$.
} 
loss $\$ 27,000$ in property wealth per pupil?

There are two possible explanations, which are not mutually exclusive. We have already argued that capitalization can be highly asymmetric because property-poor districts have incentives to spend money even if their residents value it at much less than a dollar per dollar spent. Put another way, Robin Hood may have made much more revenue available to property-poor districts, but the value they created with the revenue may have been insufficient to substantially increase household demand to live in the districts. It is demand, not school spending per se that bids up property prices. Second, it is possible that, even if demand increased substantially, the supply of vacant or low-use agricultural land was so great in property-poor districts that prices were bid up only slightly. In other words, their supply curve for residential land is rather flat.

We cannot directly test the first explanation (if feasible, it would require a separate study), so we leave it as the residual explanation. However, we should be able to see clear signs of the second explanation. Property-poor districts should disproportionately convert land to residential use and should have disproportionate growth of housing units. (We say "disproportionate" because there will be some land conversion and new housing in all districts, simply because Texas' overall population grew in the 1990s.) In Appendix Figures 1 through 3, we examine property use in the 1990s. We see a small percentage of land converted to residential use in all districts, but see no sign that property-poor districts converted land any faster than intermediate or property-rich districts.

We also regressed the decadal changes in districts' housing units on the decadal changes in the populations of their metropolitan area (county for non-metropolitan districts), indicators for the decade, indicators for their property wealth quantile, and, most importantly, indicators for their property wealth quantile interacted with the indicator the decade being the 1990s (the Robin Hood period). Specifically, the regression is:

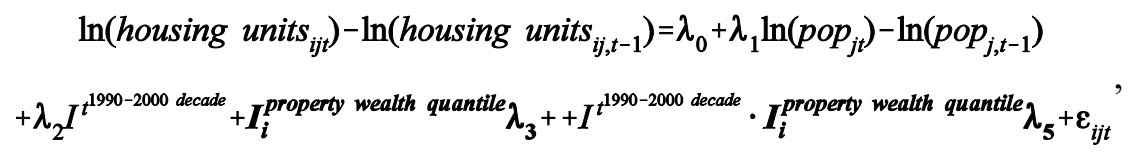


where if $t$ is 1990 , then $t-1$ is 1980; and if $t 2000$, then $t-1$ is 1990. If property-poor districts added housing units disproportionately after Robin Hood, then the coefficients on their interaction terms will be positive and statistically significantly different from zero. In fact, Appendix Table 1 shows that none of the interaction terms has a coefficient that is statistically significantly different from zero, except that quantile 19 has a positive coefficient that is marginally significant at the 10 percent level. In other words, disproportionately high growth in housing units in the 1990s occurred only in the second property-richest group of districts - probably because most of these districts that were unaffected by Robin Hood for much of the 1990s (too property-rich to participate in the guaranteed revenue system and too property-poor to experience recapture until the late 1990s). ${ }^{49}$

In short, neither the land conversion evidence nor the housing units evidence supports the hypothesis that demand for homes in the property-poor districts grew substantially. Demand for these districts apparently failed to increase; it is not merely that the supply of residential property in these districts was highly elastic. We conclude that Robin Hood generated only a little positive capitalization in property-poor districts because their value to residents rose only by a little.

The capitalization result that surprised us was the consistent pattern of small negative capitalization in intermediate districts like those in quantile 10 (quantiles 7 through 13 look similar). These intermediate districts experienced a negligible change in their net foundation aid, lower marginal tax prices, and no recapture because they were insufficiently property-rich to hit the recapture threshold. The one parameter that significantly worsened for such districts was share kept $_{i j t}$. That is, after Robin Hood, if staff effort raised property values, the district simply paid more property taxes: the school

\footnotetext{
49 In other words, until the recapture threshold fell significantly and swept them into recapture in the late 1990s, a fair number of districts in quantile 19 were unaffected by Robin Hood. Not surprisingly, households that might otherwise have moved into quantile 20 districts (all of which experienced recapture) may have built homes in quantile 19 districts, generating the result we see in Appendix Table 1.

In Appendix Table 1, the coefficient for the property-poorest districts (quantile 1) is a positive 0.11, but we cannot make much of this since it is not significant at any conventional statistical level and the coefficients for all the other property-poor quantiles are negative.
} 
budget did not benefit at all. We hypothesize that, by eliminating an incentive device, Robin Hood may have decreased the value of schools, thereby generating a small amount of negative capitalization in intermediate districts.

\section{Assessed or Market Property Values?}

So far, we have examined assessed property values, but it is possible that the capitalization is more fictional than real. That is, it is possible that only the assessed or book values of property fell in Texas, not the market values. On the other hand, the state has an incentive to prevent variation in assessment practices, which could undermine its system of aid, causing it to give disproportionate aid to districts with underassessed property values. In an effort to monitor its county-based assessors, Texas' Comptroller annually computes a ratio of assessed to market value for each school district, basing its computation on a sample of all property sales that occurred during the year..$^{50}$

In Figures 14 through 17, we use the ratios of assessed-to-market value from the Comptroller's annual studies to investigate whether Robin Hood affected market property values, or merely assessed values. Figure 14 shows average assessment ratios from 1988 to 2001 for all of the major types of property in Texas: single family homes, multiple family homes, vacant property, commercial property, utilities property, and minerals property (which includes oil and gas property). We see no trend over time toward underassessment. Instead, we see assessment ratios trending toward one, for all categories of property, suggesting the Comptroller's monitoring has succeeded in bringing assessed values into line with market values. It is not surprising to see evidence of increased scrutiny during a period when the state's level of intervention in school finance has increased.

In Figures 15 through 17 (which are all on the same scale as Figure 14), we show assessment

\footnotetext{
50 The technical descriptions of the computations suggest to us that they are highly reliable. The sampling is too detailed to describe here, but suffice it to say that the comptroller collects a value-stratified sample that is sufficiently large to produce a 95 percent confidence interval of length 0.1 in each school district. That is, a typical 95 percent confidence interval is 0.95-1.05 around a mean assessment ratio of 1 .
} 
ratios by property wealth quantile for single family homes, commercial property, and minerals property. These figures would allow us to spot a trend toward underassessment in, say, property-rich (quantile 20) school districts, even if assessment ratios in other districts were close to one. We see no evidence of trends toward underassessment in any quantile. Indeed, assessed values of all types, in all quantiles, are increasingly in line with market values.

\section{Robin Hood's Other Consequences}

We now briefly investigate how Robin Hood affected property tax rates, disability classification in Texas, and school spending.

\section{A. The Consequences of Robin Hood for Property Tax Rates}

We predicted above that Robin Hood would affect property tax rates. The property-poor districts had incentives to raise their tax rates because each dollar they raised allowed them to spend multiple dollars. Indeed, property-poor districts had to raise their property tax rates in order to get much aid from Robin Hood because the scheme gave them only modest increases in their foundation aid and made it impossible for their budgets to rise with their property values. Figure 18 shows that the tax rates of property-poor districts did rise. We see that the property-poorest districts (quantile 1) raised their tax rates from about 12 mils to 14.2 mils following the full implementation of Robin Hood in 1994-95.

Figure 18 shows that intermediate districts (quantile 10) also experienced rising property tax rates. Recall that, with Robin Hood, these districts experienced lower marginal tax prices and a small amount of negative capitalization. The predictable consequence was that they chose higher property tax rates. In 1991, their average tax rate was 12.6 mils. After 1994, it hovered between 14 and 14.7 mils.

However, it is the property-rich districts that experienced the steepest rise in property tax rates.

Figure 18 shows that, immediately after the recapture system started, their tax rates rose from 12.5 mils to 14 mils. However, because the state kept reducing the recapture threshold in its 
perennial search for funds, property-rich districts had to raise their tax rate every year just to maintain spending (setting off yet another round of capitalization!). They are now at the 15 mil cap, and we cannot say how high their rates might be in the absence of the cap. In anything, Figure 18 suggests that their rates would still be rising. These districts literally cannot spend anything more per WADA: they cannot raise their tax rates; they cannot derive higher budgets from rising property values because all marginal revenue from that source is captured. Raising the ratio of their WADA to pupils is their sole means of obtaining additional spending.

\section{B. The Consequences of Robin Hood for Disability and Other Student Classification}

The Robin Hood system is based on property wealth per WADA. Thus, every district has an incentive to raise its ratio of WADA to pupils to minimize its "book" wealth. As just seen, however, raising WADA is the sole means by which property-rich districts at the cap can raise spending. A property-poor district has incentives to raise WADA because it makes both foundation aid and guaranteed revenue aid more generous. A small number of "gap" districts have only very mild incentives to raise WADA because they are too property-rich to receive guaranteed revenue aid and too propertypoor to experience recapture. In such districts, the costs associated with reclassifying a student might easily offset the only benefit of higher WADA: a higher foundation grant. ${ }^{51}$

Figure 19 shows that the WADA/pupil ratio of quantile 1 (property-poor) districts rose from 1.36 to 1.42. The WADA/pupil ratios of quantile 20 (property-rich) districts rose much more: from 1.3 to 1.62. If it were not for Robin Hood's incentives, such WADA/pupil ratios would be very surprising in relatively affluent districts. The WADA/pupil ratios of districts with only mild incentives to raise

\footnotetext{
51 Raising WADA raises a district's foundation grant because the same pupil classifications that raise WADA raise the multipliers that generate a district's foundation grant.

We classify a district as having mild incentives to raise the WADA/pupil ratio if its only benefit from raising WADA is getting greater foundation aid. We use the following rule to find such districts: a district must not not receive guaranteed revenue aid; must not be able to get guaranteed revenue aid by raising its W ADA by 5 percent; must not experience recapture; and must not be put into recapture status by an 5 percent decrease in its WADA. That is, we find districts that are not only in the gap between the guaranteed revenue and recapture system, but also a little distance from the thresholds for those systems.
} 
WADA did not change much over the period: they hovered in the range around 1.27.

This evidence strongly suggests that districts responded to Robin Hood's incentives to raise WADA. It confirms Cullen's (2003) study of disability classification in Texas. The main consequence of WADA "inflation" is probably distortions in how students are taught. Although WADA inflation has consequences for the stability of school finance in Texas, they are less than one might think because nearly all districts are simultaneously inflating WADA: the average WADA to pupil ratio in Texas districts rose from 1.27 in 1991 to 1.36 in 2002 . As a result, the property-rich districts are paying less per actual student than they were intended to pay, but -offsetting this- the property-poor districts are getting more per actual student than they were intended to get.

\section{The Effects of Robin Hood on the Average Level and Equality of Per-Pupil Spending}

People often ask whether a school finance program leveled-up or leveled-down. That is, did it cause average per-pupil spending in the state to rise faster or slower than it otherwise would have? Figure 20, which shows Texas' average per-pupil spending and that of a few comparison states, provides one indicator of the answer. We chose comparison states with care. Oklahoma and Louisiana are not only Texas' neighbors, but also share its dependence on the oil and gas industry. California also has an oil and gas industry, experiences much of the same immigration as Texas, and had metropolitan areas (like Austin, Texas) affected by the high technology boom in the 1990s. First, note that in the pre-Robin Hood period (1980 to 1989), Texas had the highest rate of growth in per-pupil spending among the four states. Over the subsequent decade, under the influence of school finance reform (1989 to 1999), Texas' average per-pupil spending grew at much the same pace as spending in the comparison states. ${ }^{52}$ Over the briefer period of full Robin Hood implementation, from 1994 to 1999, Texas' average per-pupil spending grew at the same pace as Louisiana's, very slightly faster than that of California, and faster than that of

\footnotetext{
52 Data on the comparison states' per-pupil spending are not yet available for years after the 1999-2000 school year.
} 
Oklahoma.

Figure 21 presents two more indicators of whether Robin Hood leveled up or down: Texas' average per-pupil spending as a percentage of per-capita personal income and as a percentage of percapita gross state product. Both of these percentages rose throughout the 1980s and then remained stable throughout the 1990s. There is no sign of an increase in the percentages after Robin Hood's full implementation in 1994. In summary, Figures 20 and 21 suggest that Robin Hood neither leveled-up nor leveled-down. It probably had little effect on the average level of school spending in the state.

Of course, the primary aim of school finance schemes is reallocation of school spending. Changing average spending is a secondary goal, if it is a goal at all. In Figure 22, we show per-pupil spending from 1991 to 2001 for property wealth quantiles $1,5,10,15,19$, and $20{ }^{53}$ There has been narrowing of the spending gap, especially among the first through the 95th percentiles of the property wealth distribution. Over the decade, the coefficient of variation in per-pupil spending fell from 0.22 to 0.12. The spending gap between the lowest and highest spending quantiles narrowed from about $\$ 2,200$ to about $\$ 1,800$. Note that the property-poorest quantile typically does not spend the least per pupil in Texas: the lowest spending districts tend to have per-pupil property wealth between the 25 th and 50th percentile.

In Table 5, we show regression estimates of the effects of the school finance parameters on perpupil spending. We are less interested in the individual coefficients than in their implications for the dispersion of school spending. Nevertheless, examine the coefficients briefly. The increased marginal tax prices have little effect on property-rich districts' per-pupil spending (the point estimates are negative but statistically insignificant). However, for every halving of the marginal tax price in property-poor districts, per-pupil spending rises by 13.56 percent. The coefficient on the virtual lump sum grant

\footnotetext{
53 We cannot include the $1980 \mathrm{~s}$ in this figure because the only district-level data on per-pupil spending for the 1980s are from a different source, the 1981-82 and 1986-87 Censuses of Governments. We found these data insufficiently comparable to be useful for Figure 16.
} 
suggests that doubling it would raise spending by 0.9 percent, but we acknowledge that this coefficient may understate the true effect because Robin Hood generated such modest variation in foundation grants. We are not surprised to see a negative coefficient on share kept $_{i j t}$ (see discussion above), but we have no especially good interpretation of its small but statistically significant effect. Share kept $t_{i j t}$ fell by 0.33 for property-poor districts in quantile 1 , implying an 0.8 percent increase in their spending. It fell by 0.67 for property-rich districts in quantile 20, implying a 1.8 percent increase in their spending.

Using the results shown in Table 5, we estimate that Robin Hood reduced the coefficient of variation in per-pupil spending in Texas by 0.11 and reduced the gap between the lowest spending quantile and highest spending quantile from about $\$ 2000$ to $\$ 1500$ (the exact number depends on the "after Robin Hood" year). ${ }^{54}$ These summary statistics accord well with our graphical view of the dispersion of per-pupil spending, shown in Figure 22.

\section{Did Robin Hood Efficiently Take from the Rich to Give to the Poor?}

Table 6 contains summary statistics to help us see the big picture -how has Robin Hood worked as a school finance scheme designed to equalize school spending? We use statistics based on the coefficient estimates in Tables 4 and 5, but there is nothing mysterious about them. They could almost be read off graphs like Figures 9 through 22.

The left-hand columns show the benefits of Robin Hood: it caused the coefficient of variation in per pupil spending to fall by 0.11 and caused the spending gap between the highest-spending and lowestspending quantile to fall by about $\$ 500$. These are not insignificant gains in school spending equality, but school spending was not equalized in Texas. The middle column shows that $\$ 1,482$ per pupil would be needed to give all schools in Texas spending equal to the highest quantile's spending.

The right-columns in Table 6 show the costs of Robin Hood, which -interestingly- are indicated

54 Both numbers are in 2002 dollars, adjusted using the CPI. 
by aggregate capitalization. Why is this? Robin Hood distorts households' choices about homes, schools, and other consumption. Some households undoubtedly liked their pre-Robin Hood packages better; some liked their post-Robin Hood packages better. To the extent that value is merely changing hands, the scheme is not costly. Robin Hood is costly only when some households lose consumption or schooling they valued and other households do not get offsetting gains. Because property values capitalize the value of services bought with taxes, aggregate capitalization automatically nets out the benefits of the Robin Hood program and is an accurate measure of its costs. (We are often asked whether people who move to Texas in the future will somehow benefit from today's net negative capitalization because they will pay less for homes. The answer is no. Property values capitalize the costs and benefits of districts' schools. Movers to Texas will pay less for their homes on average because the school systems and homes will be, on average, worth less to them. They will not be getting especially good deals.)

Net losses of property wealth in Texas were about $\$ 27,000$ per pupil (more in the later years). We cannot directly compare the losses to, say, the amount we need to fill to the spending gap, which is shown in the middle column. This is because the loss is a stock and the gap is a flow (an amount needed every year). Nevertheless, if we multiply the losses in the right hand column by a return on investment such as 5 percent, we get $\$ 1,350$ per pupil. In other words, if we could somehow invest the lost property wealth and use its proceeds for redistribution, we could eliminate nearly all inequality of per pupil spending in Texas and raise the average level of spending to the level of the highest spending quantile.

Was Robin Hood efficient at taking from the rich and giving to the poor? Certainly not if the alternative was efficient confiscation of wealth. If the state had simply confiscated $\$ 27,000$ per pupil in assets from the wealthy, it could have endowed a fund to nearly equalize school spending (as described above). Efficient wealth confiscation is not a realistic policy option in the United States, but an income or payroll tax might be a realistic alternative to the recapture system. Since Texas currently has neither 
tax and a tax rate of less than $2 \%$ would be necessary to replace recapture, Robin Hood could almost certainly have been funded without generating much deadweight loss.

Why is Robin Hood so inefficient? There are two reasons. First, by relying on property as the basis of the tax and the aid, the system invites capitalization. Capitalization makes the tax base shrink much faster than we are used to seeing with a typical tax. As a result, tax rates have to rise. Because deadweight loss is approximately proportional to the square of the tax rate, the high tax rates induced by Robin Hood (most Texans now pay a 19 percent rate on housing services) are inefficient. It should be emphasized that there is no reason why Robin Hood had to be based on property values. Other states fund aid with taxes on income or sales and distributed aid on the basis of household incomes. ${ }^{55}$

Second, Robin Hood is inefficient because the scheme does not make good use of the foundation system, which is more lump-sum in nature than the guaranteed revenue or recapture systems. That is, a self-supporting foundation system takes a lump of revenue from each rich district, gives a lump of revenue to each poor district, and then sets all districts' marginal tax prices to one. Indeed, it is quite possible to have a foundation aid system based on income and not property values, so that it induces almost no capitalization. ${ }^{56}$ The foundation component of Robin Hood is minor -the law hardly raised most districts' foundation grants. It is Robin Hood's guaranteed revenue system that generates most of the aid for poor districts. Moreover, the rich districts do not contribute through the foundation system at all -their marginal property value is taxed instead.. In short, Robin Hood minimizes reliance on lump sum redistribution and maximizes reliance on high marginal tax rates. This is unnecessary: numerous states rely largely or wholly on foundation systems, which can be generous.

55 In Texas, it would probably be necessary to base both on household incomes and income from oil and gas property. The state already measures the implied income of oil and gas producers in order to compute their property value assessments.

56 A foundation aid system based on property values generates more capitalization than one based on incomes because (a) the foundation grant varies with property values and (b) foundation aid reduces share kept $_{i j t}$ which affects property values, as we have seen. 
Texas' Robin Hood scheme unintentionally contained the seeds of its own self-destruction. A better understanding of how school finance works might lead to the adoption of schemes that are more efficient, more stable, more equalizing, less burdensome to taxpayers, and -in the long run- more likely to achieve the goals of school finance.

\section{References}

Cullen, Julie Berry, 2003. "The Impact of Fiscal Incentives on Student Disability Rates," Journal of Public Economics, 87(7-8):1557-89.

Calabreze, Stephen, and Dennis Epple, 2004. "On the Political Economy of Tax Limits," CarnegieMellon typescript.

Epple, Dennis, R. Filimon, and Thomas Romer, 1984. "Equilibrium Among Local Jurisdictions: Toward an Integrated Treatment of Voting and Residential Choice," Journal of Public Economics, 24 (August): 281-308.

Feldstein, Martin, 1995. "The Effect of Marginal Tax Rates on Taxable Income: A Panel Study of the 1986 Tax Reform Act,” Journal of Political Economy, 103 (June), 551-572.

Goolsbee, Austin, 2000. "It's Not About the Money: Why Natural Experiments Don't Work on the Rich," in J. Slemrod, ed., Does Atlas Shrug? The Economic Consequences of Taxing the Rich. Cambridge: Harvard University Press.

Hoxby, Caroline M., 1999. "The Productivity of Schools and Other Local Public Goods Producers," Journal of Public Economics, 74, No. 1 (November), 1-30.

Hoxby, Caroline M., 2001. "All School Finance Equalizations Are Not Created Equal," Quarterly Journal of Economics, Vol. 116, No. 4 (November), 1189-1231.

Texas Comptroller of Public Accounts, various years. School and Appraisal Districts' Property Value Study, Final Reports for years 1989 through 2002, Preliminary Report for 2003. 
Texas Education Agency, Division of Performance Reporting, 2004. Academic Excellence Indicator System, 1993-94 through 2002-03. Electronic files.

Texas Education Agency, Division of State Funding, 2004. Summary of Finances, 1984-85 through 2002-03. Electronic files.

Texas Education Agency, Division of Special Education, 2002. A Guide to the Admission, Review, and Dismissal Process. Austin, TX: Texas Education Agency.

United States Department of Commerce, Bureau of the Census, 1983. Census of Population and Housing, 1980: Summary Tape File 3f, School Districts. Electronic file. Washington, DC: United States Department of Commerce, Bureau of the Census [producer]. Ann Arbor, MI: Inter-university Consortium for Political and Social Research [distributor].

United States Department of Commerce, Bureau of the Census, 2003. School District Demographics. Electronic files. Washington, DC: United States Department of Commerce, Bureau of the Census.

United States Department of Commerce, Bureau of the Census, 2004. Intercensal Estimates of the Resident Population of States and Counties. 1980 to 1999. Electronic files. Washington, DC: United States Department of Commerce, Bureau of the Census.

United States Department of Commerce, Bureau of Economic Analysis, Regional Economic Analysis Division, 2003. Gross State Product by Industry. 1980 to 2002. Electronic files. Washington, DC: United States Department of Commerce, Bureau of Economic Analysis.

United States Department of Education, National Center for Education Statistics. School District Data Book: 1990 Census School District Special Tabulation. Arlington, VA: The MESA Group, 1994.

United States Department of Energy, Energy Information Administration, 2003. Annual Energy Review 2002. 
Figure 1

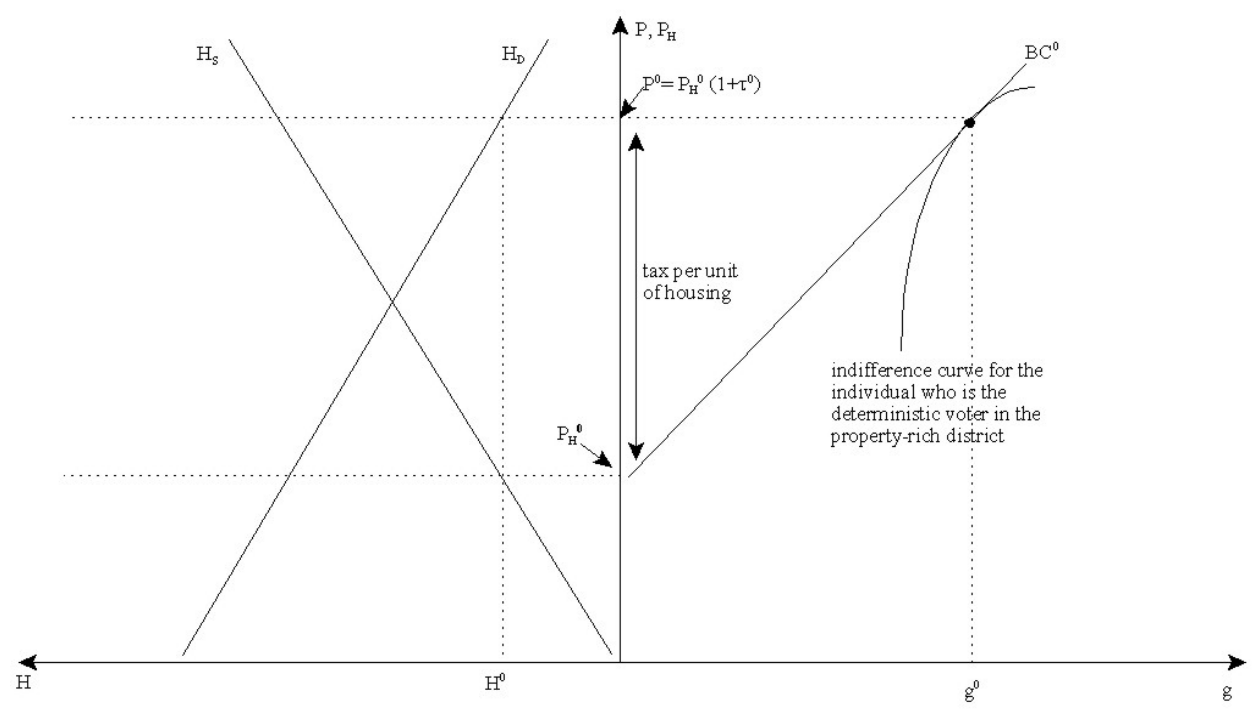

Figure 2

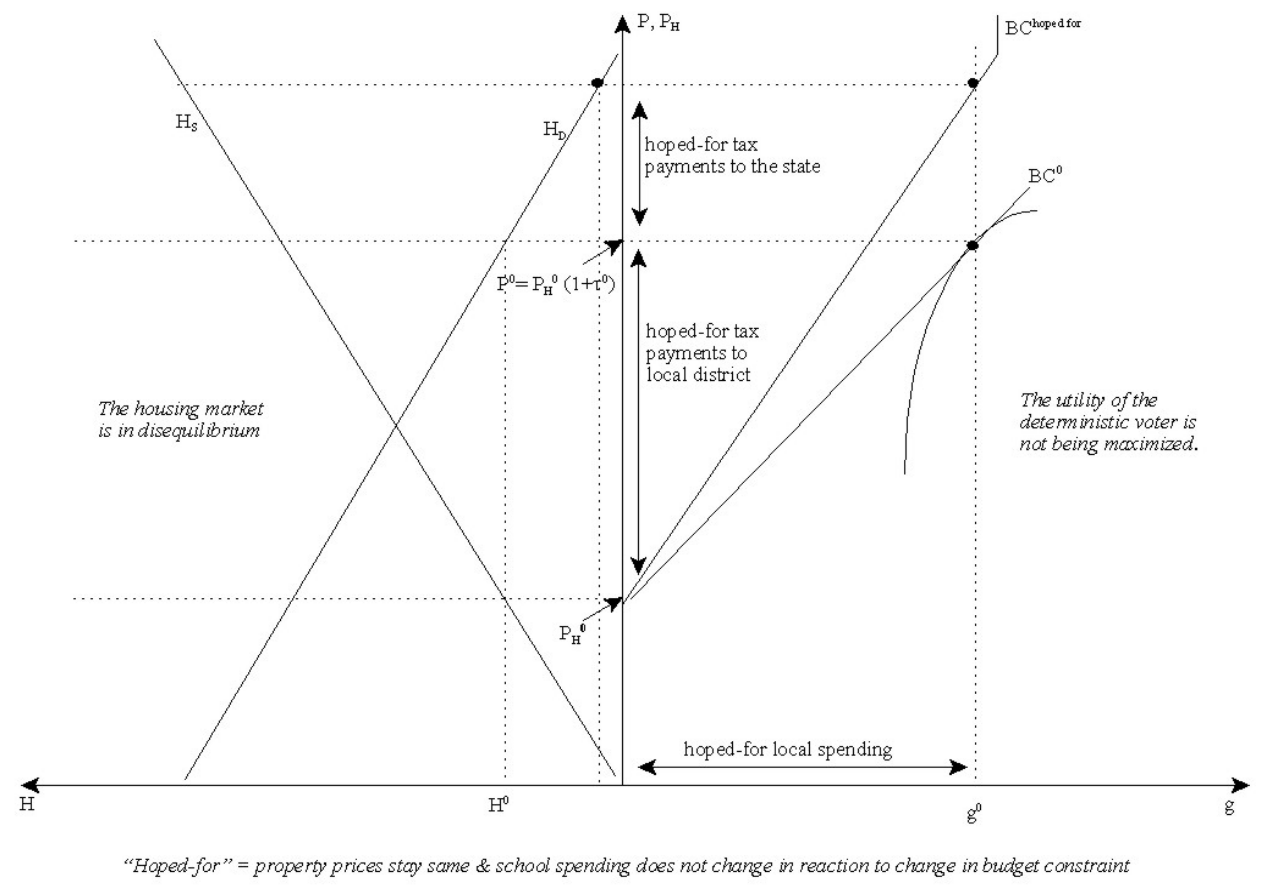


Figure 3

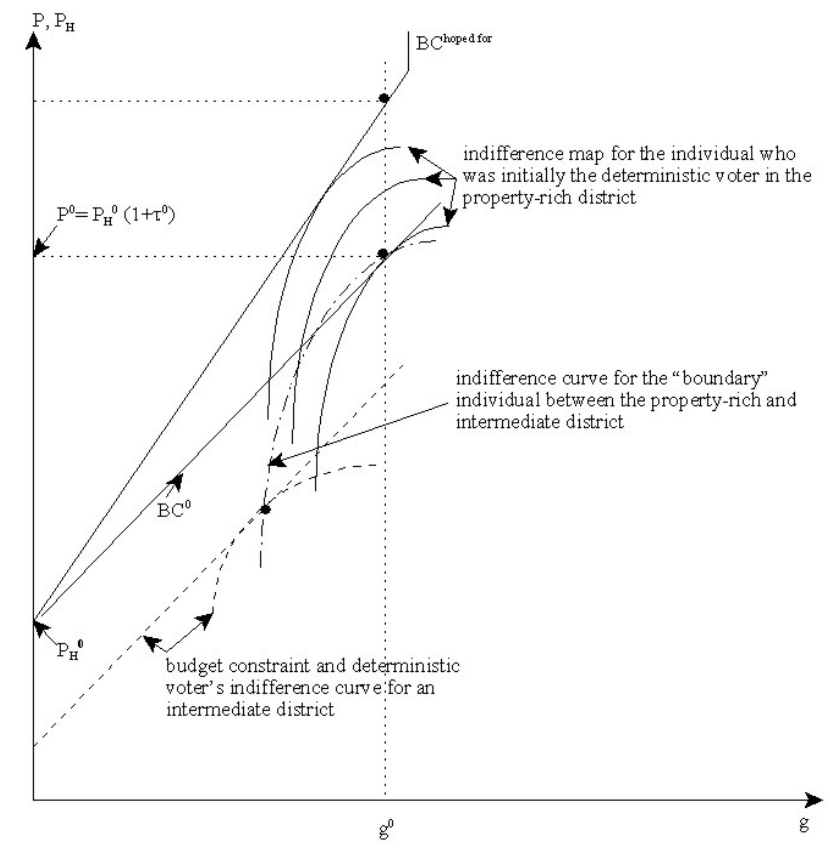

Figure 4

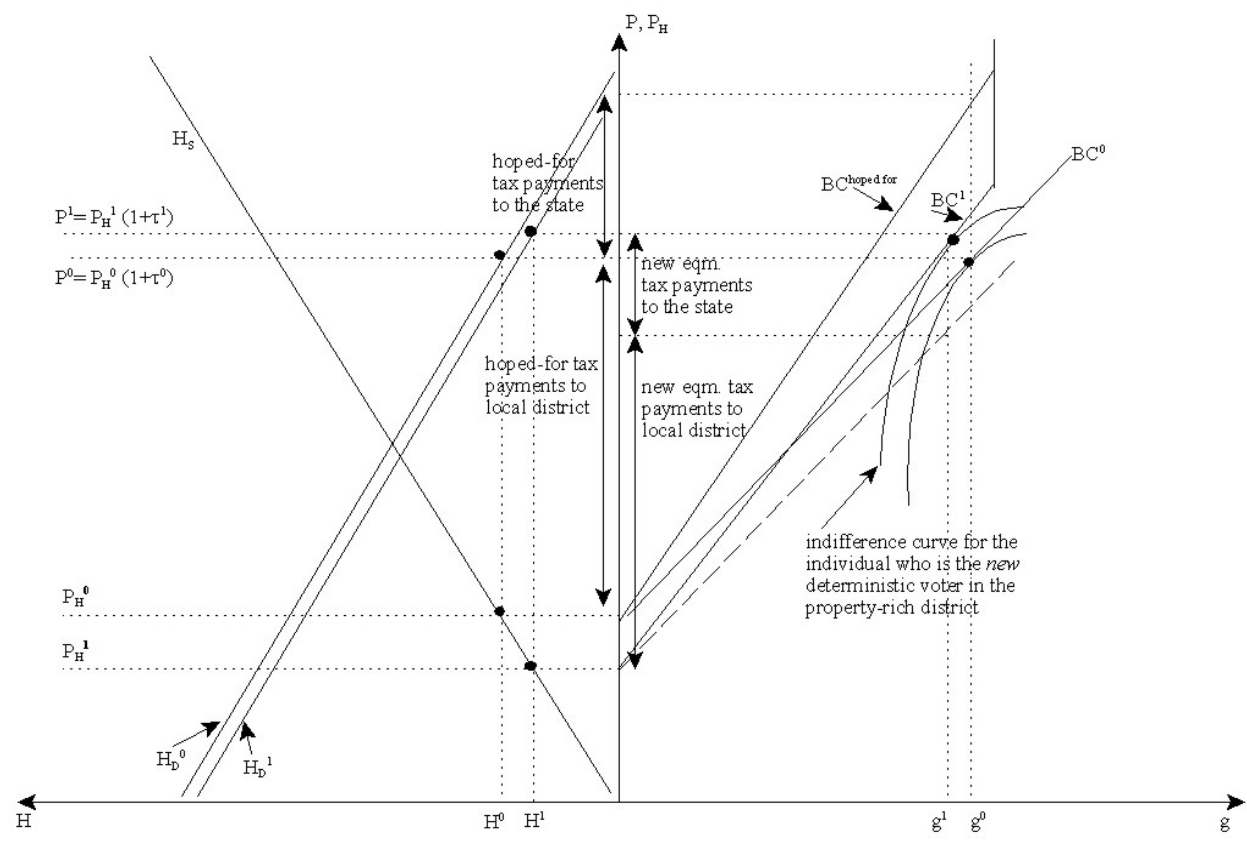


Figure 5

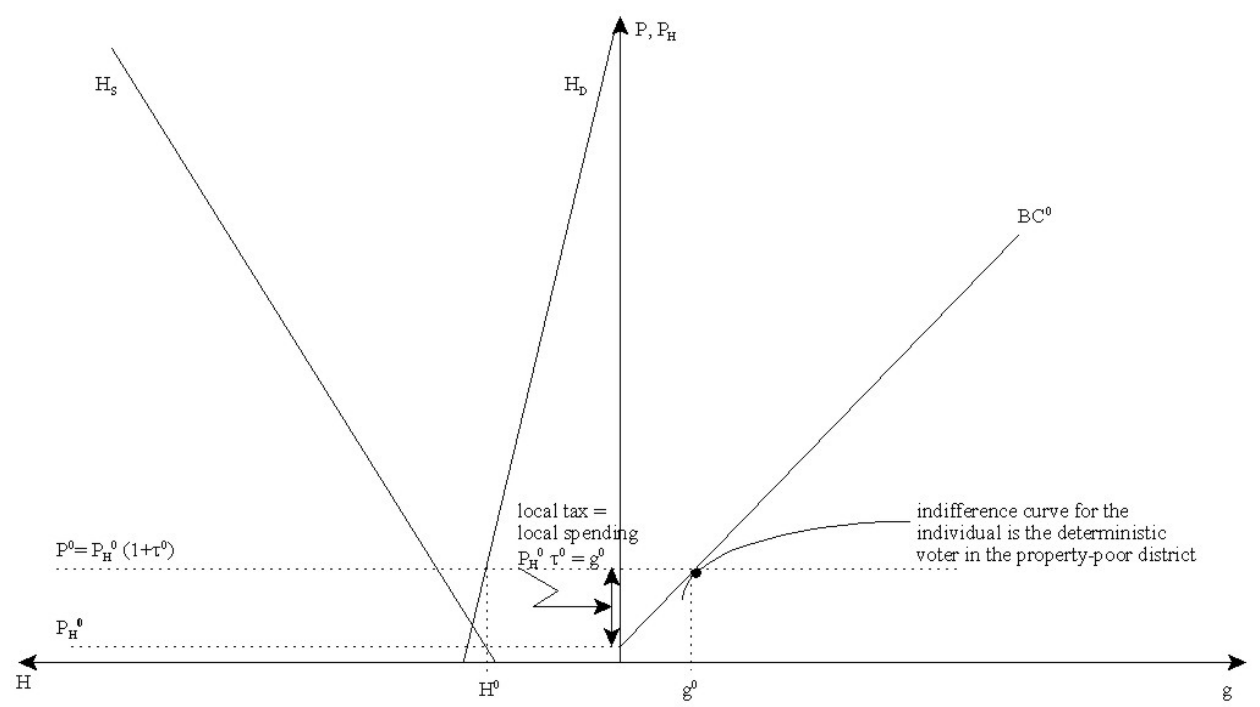

Figure 6

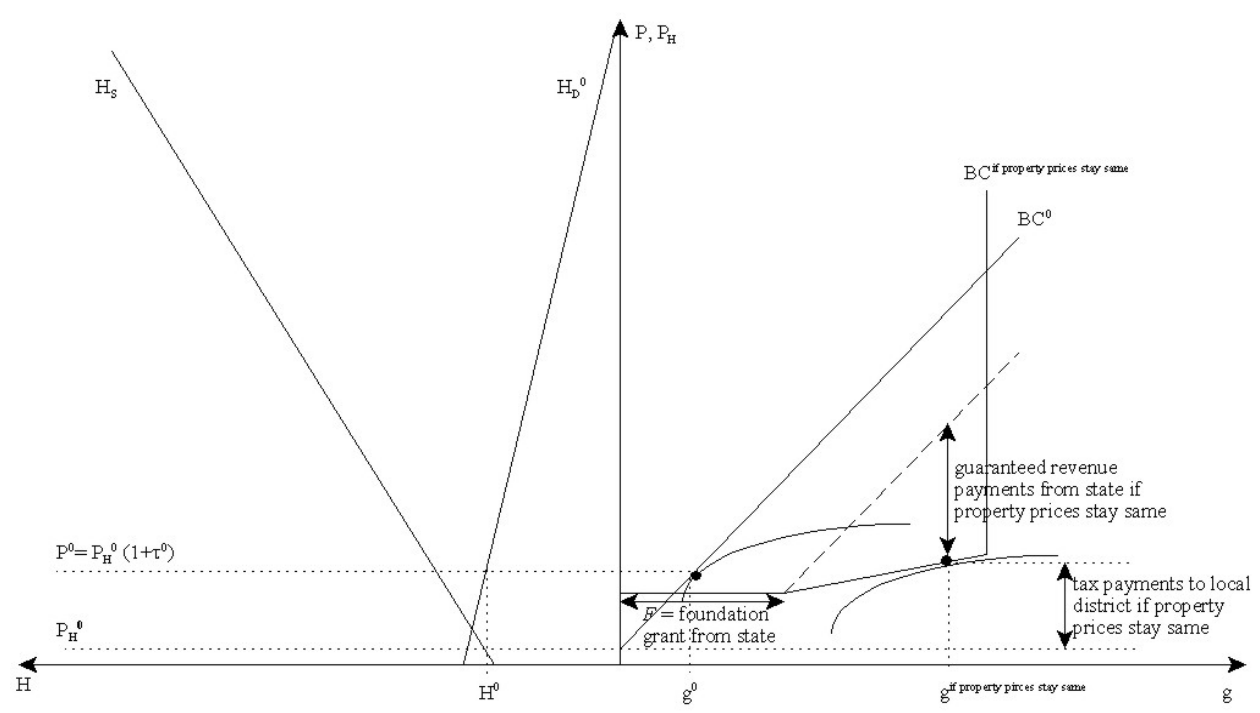




\section{Figure 7}

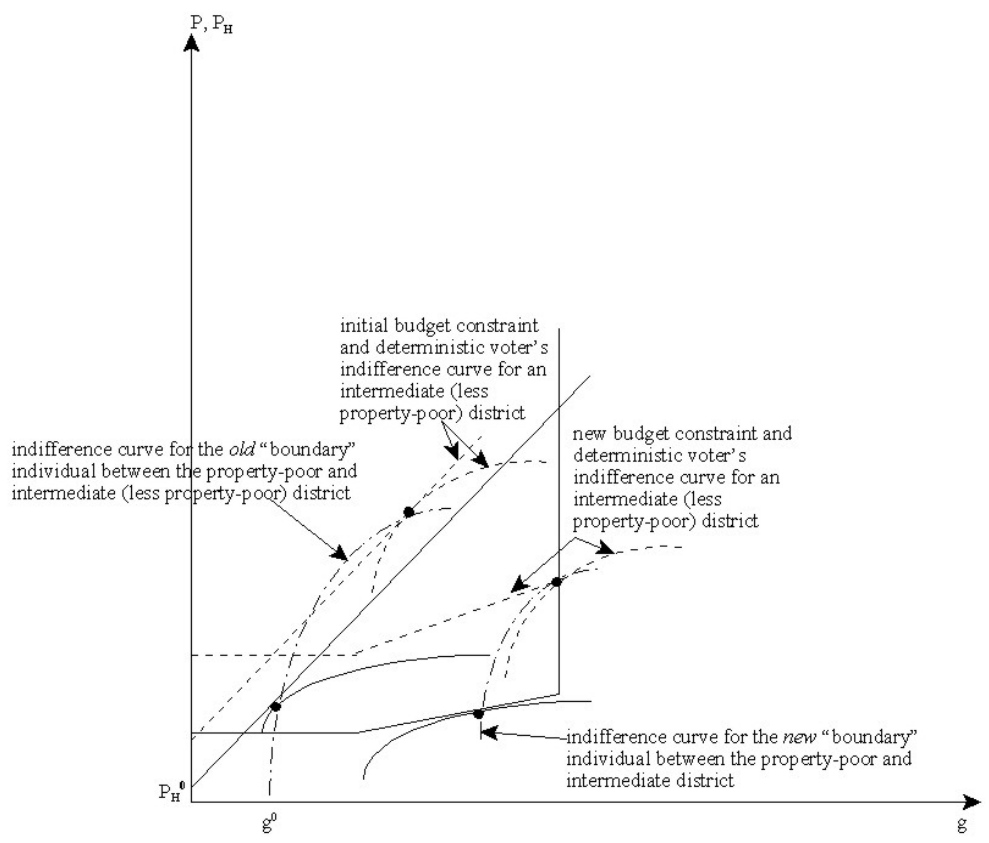

Figure 8

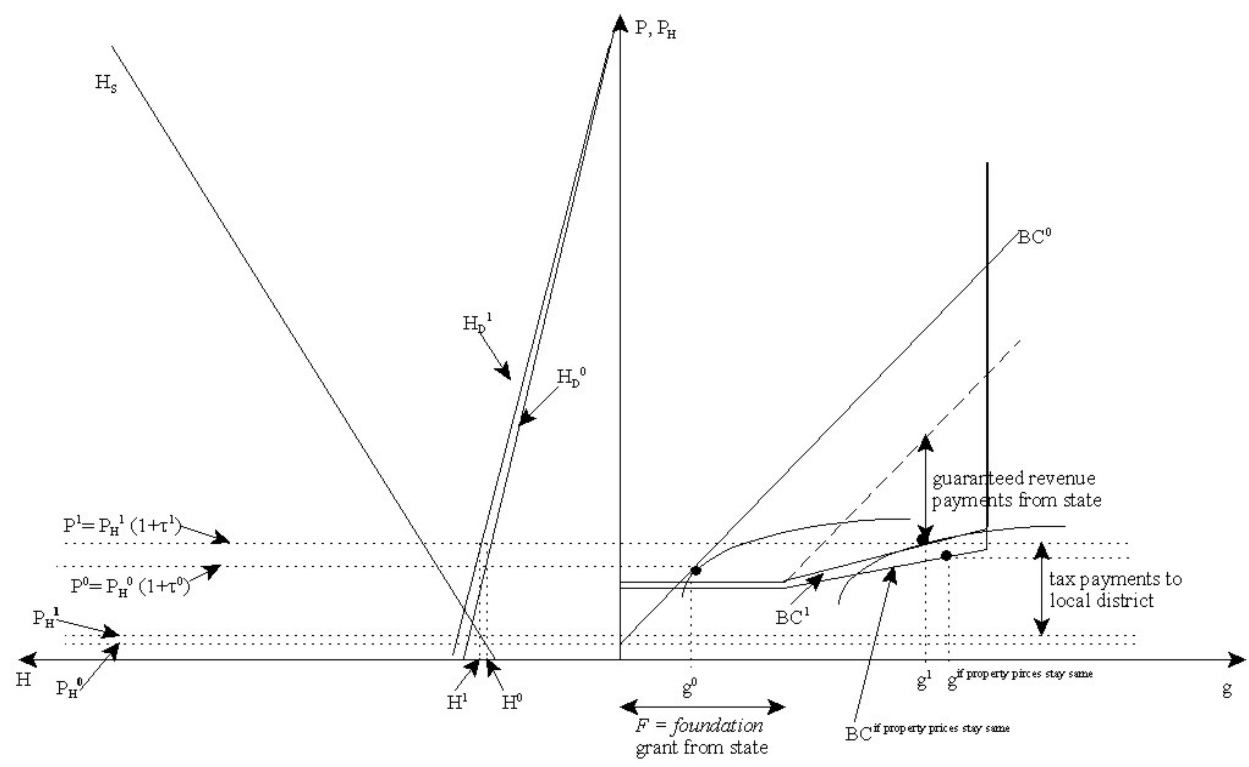




\section{Figure 9}

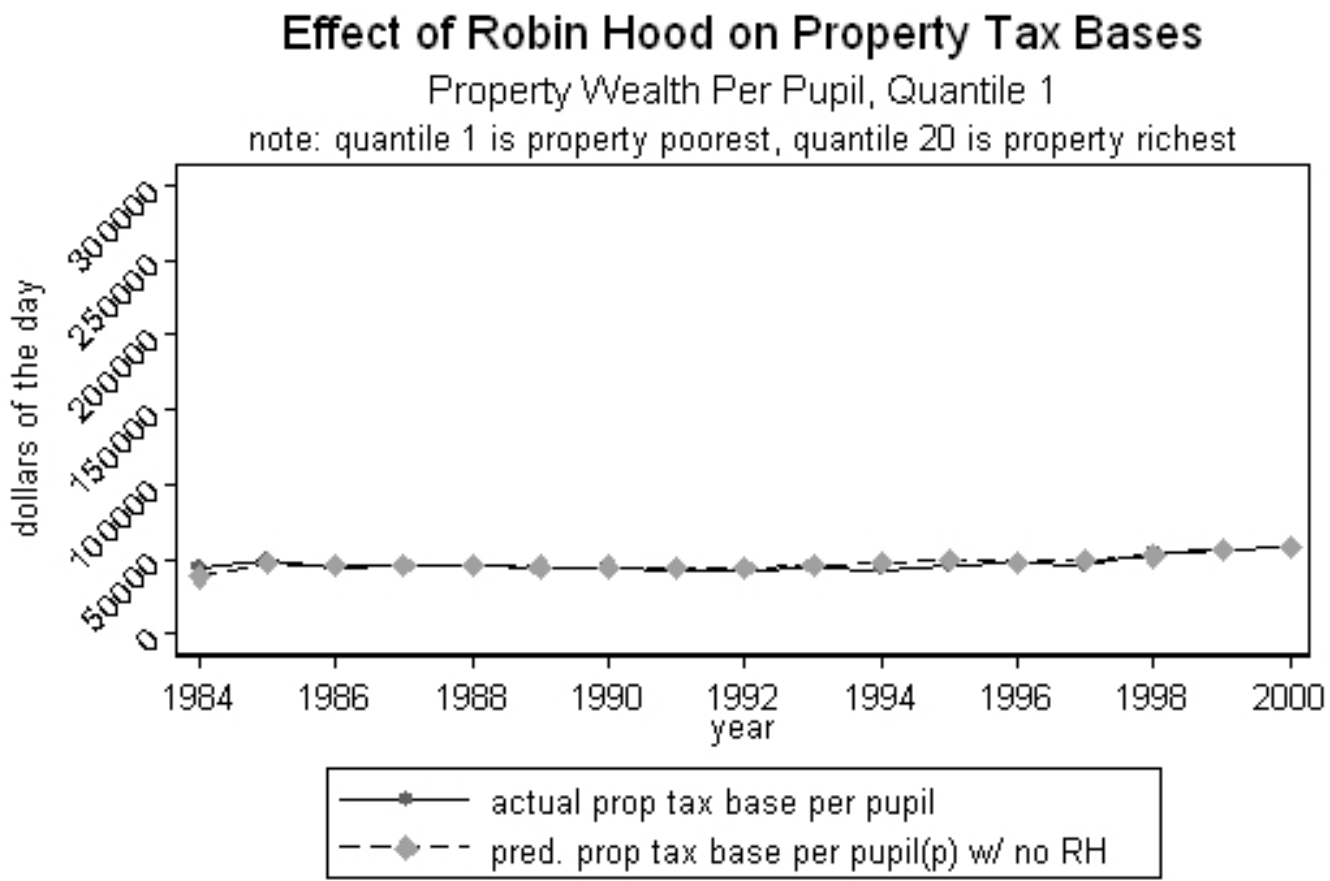

predicted=property wealth \& pupils are predicted

Figure 10

Effect of Robin Hood on Property Tax Bases

Property Wealth Per Pupil, Quantile 10

note: quantile 1 is property poorest, quantile 20 is property richest

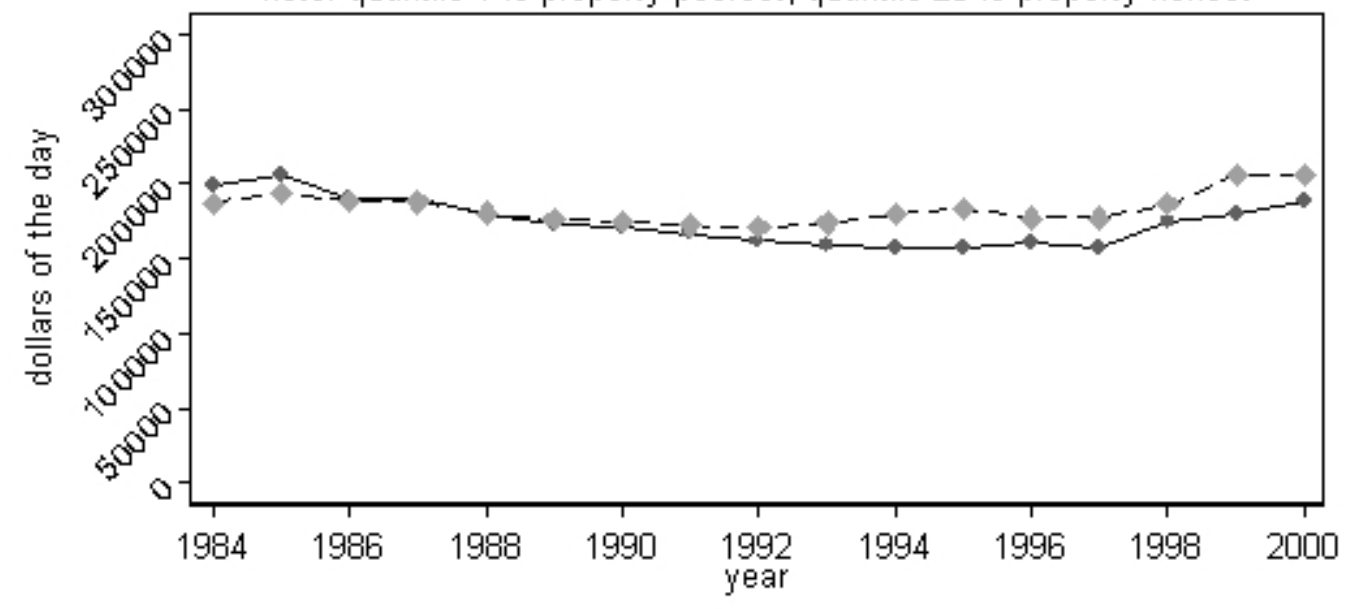

- — actual prop tax base per pupil

- - - - pred. prop tax base per pupil(p) w/ no RH

predicted=property wealth $\&$ pupils are predicted 


\section{Figure 11}

\section{Effect of Robin Hood on Property Tax Bases}

Property Wealth Per Pupil, Quantile 20

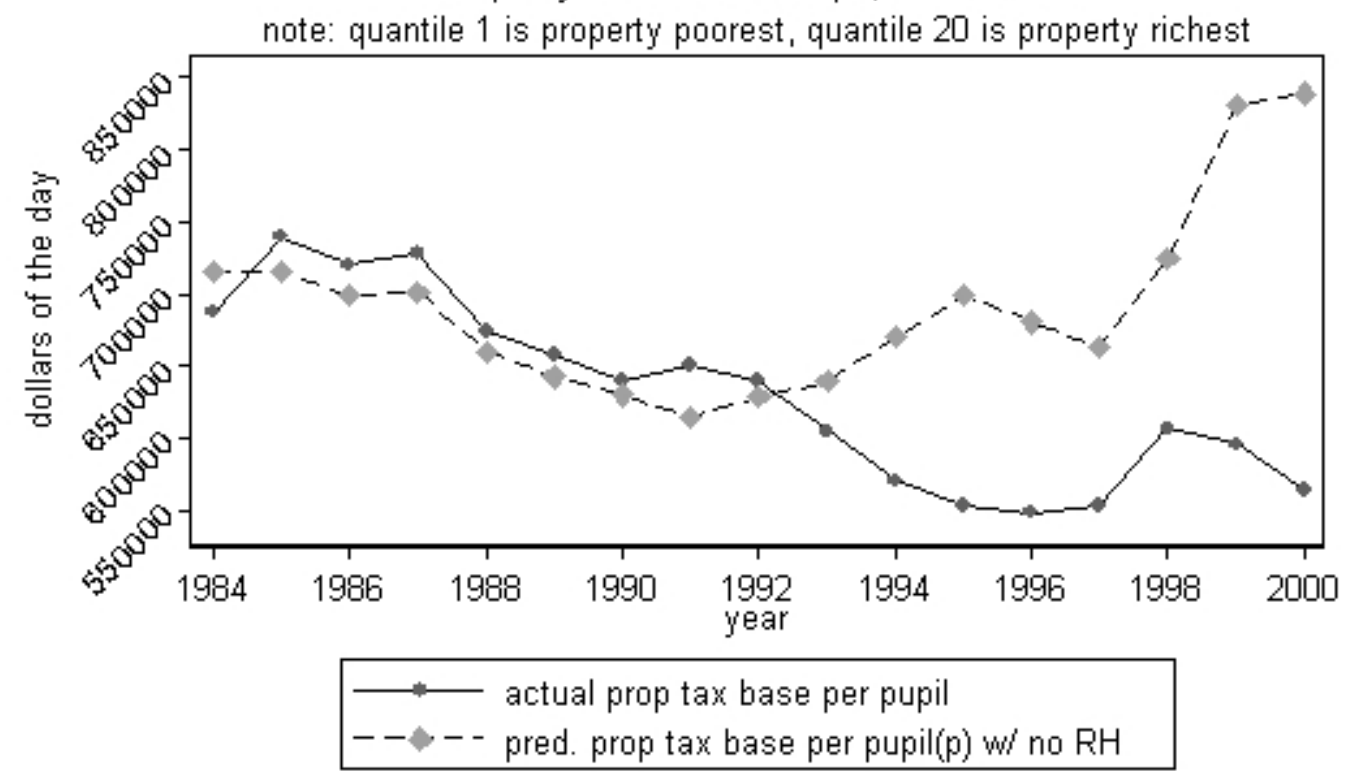

predicted=property wealth \& pupils are predicted 
Figure 12

Effect of R obin Hood on Property Tax Bases Property ive alth Per Pupil, Quantie 1

rote:q Iartle $1 \mathrm{t}$ propertypoorest, quar the $20 \mathrm{l}$ propert/relest

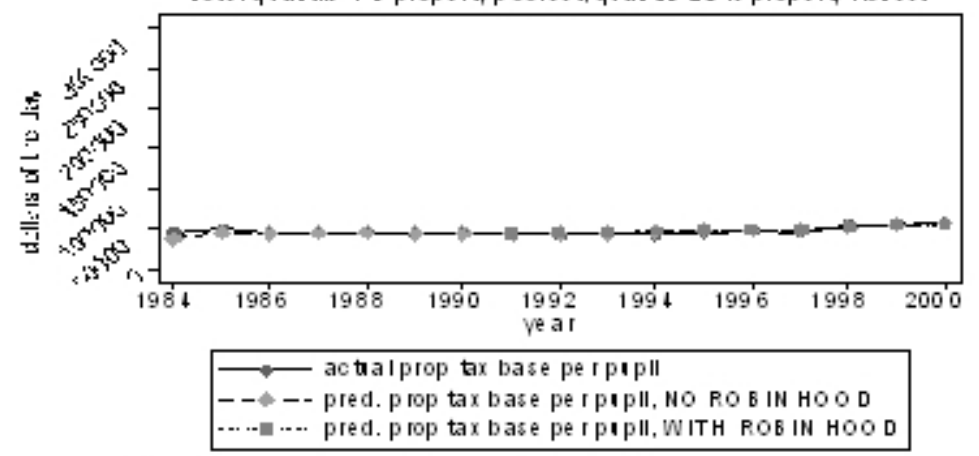

predlclon WITH RO 8 in HOO D uses regressbon desalbed In lexI
Effect of Robin Hood on Property Tax B ases Property Wiealth Per Pupil, Quantile 10

Iote:q rartle $1 \mathrm{t}$ propert/ poorest quartle $20 \mathrm{ls}$ popert/ iscest

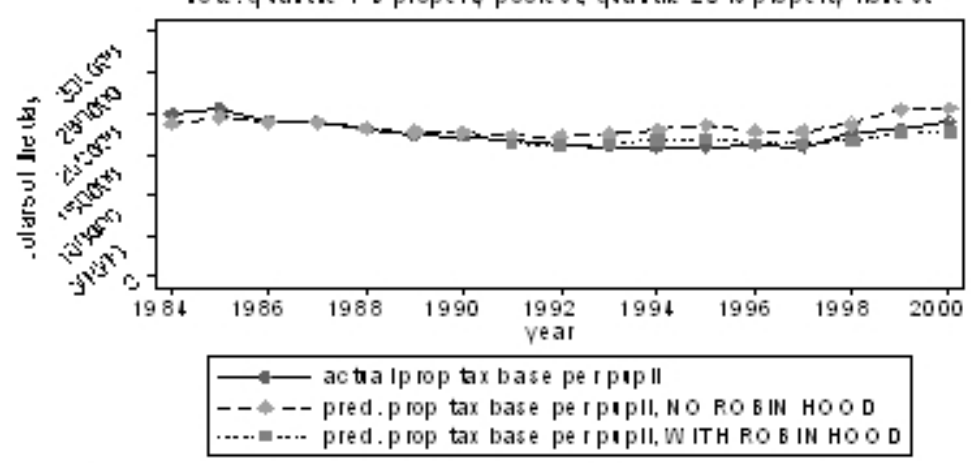

predklonwITH RO B IW HOO D uses regre ss bondes albed In lex

Effect of Robin Hood on Property Tax Bases

Property 'Wealth Per Pupil, Quantile 20

Iote : quatle $1 \mathrm{k}$ propert/poorest, qualtk $20 \mathrm{k}$ propert/ rlclest

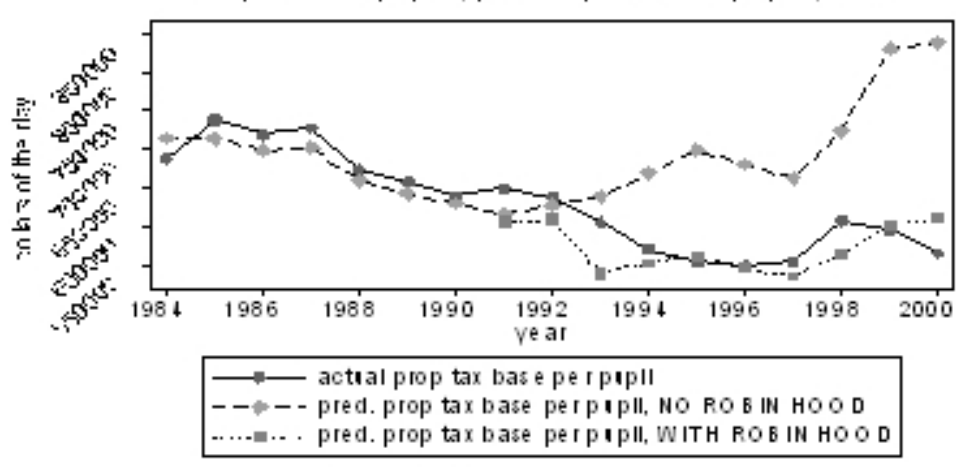

pre dlcllon WITH RO BII HOO D ue es rejresston desabed In lexI 
Figure 13

Effect of Robin Hood on Property Tax Bases Property Wivealth Per Pupi, Quantile 1

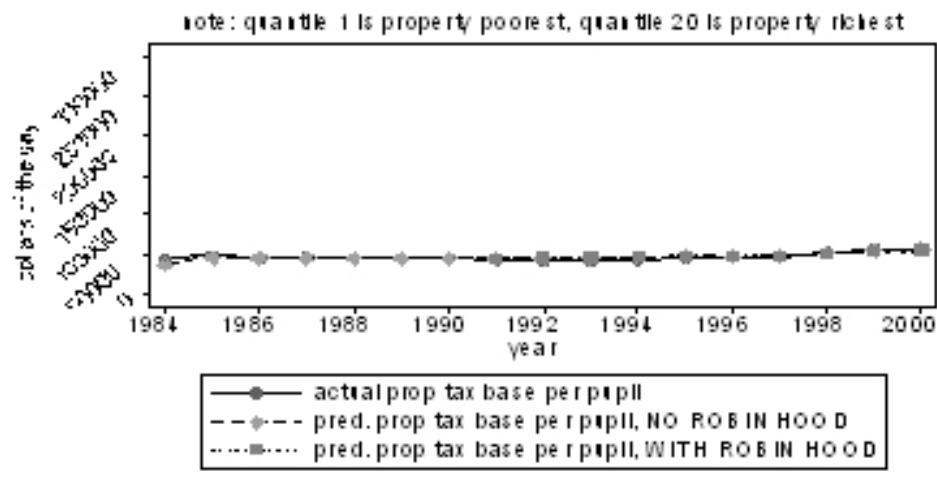

predk Ion WITH RO BIW HOO D ures regresslon descrb ed In lexI
Effect of Robin Hood on Property Tax Bases Property iviealth Per Pupil, Quantile 10

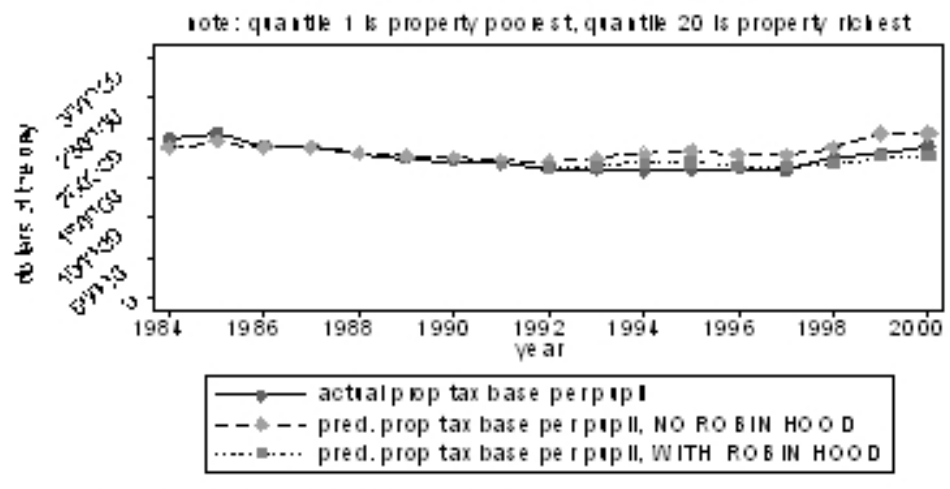

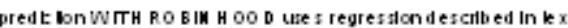

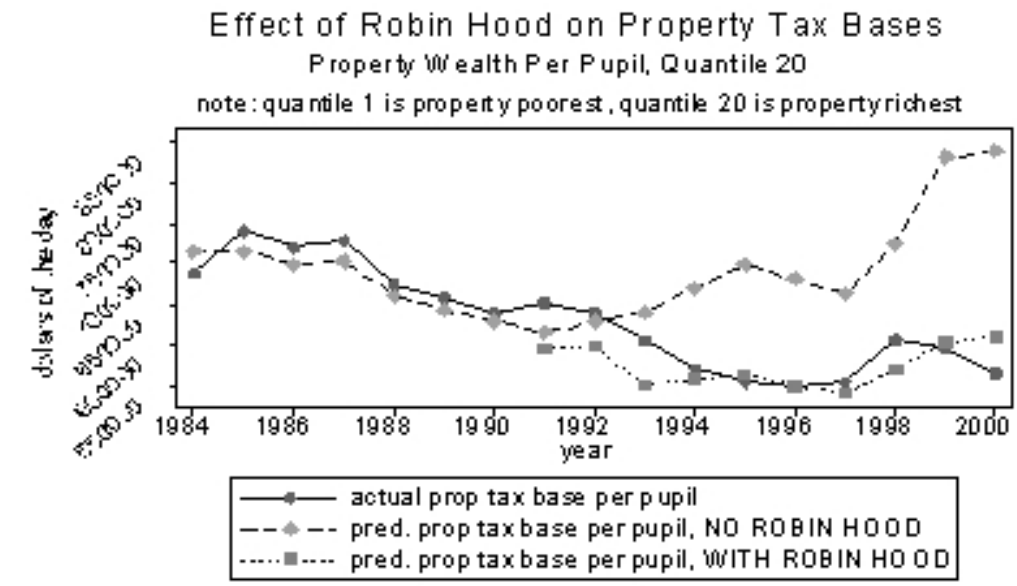

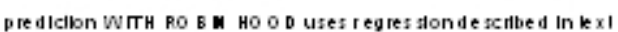


Figure 14

Effect of Robin Hood on Assessment Ratios in Texas

ratio of assessed to market value, various property types

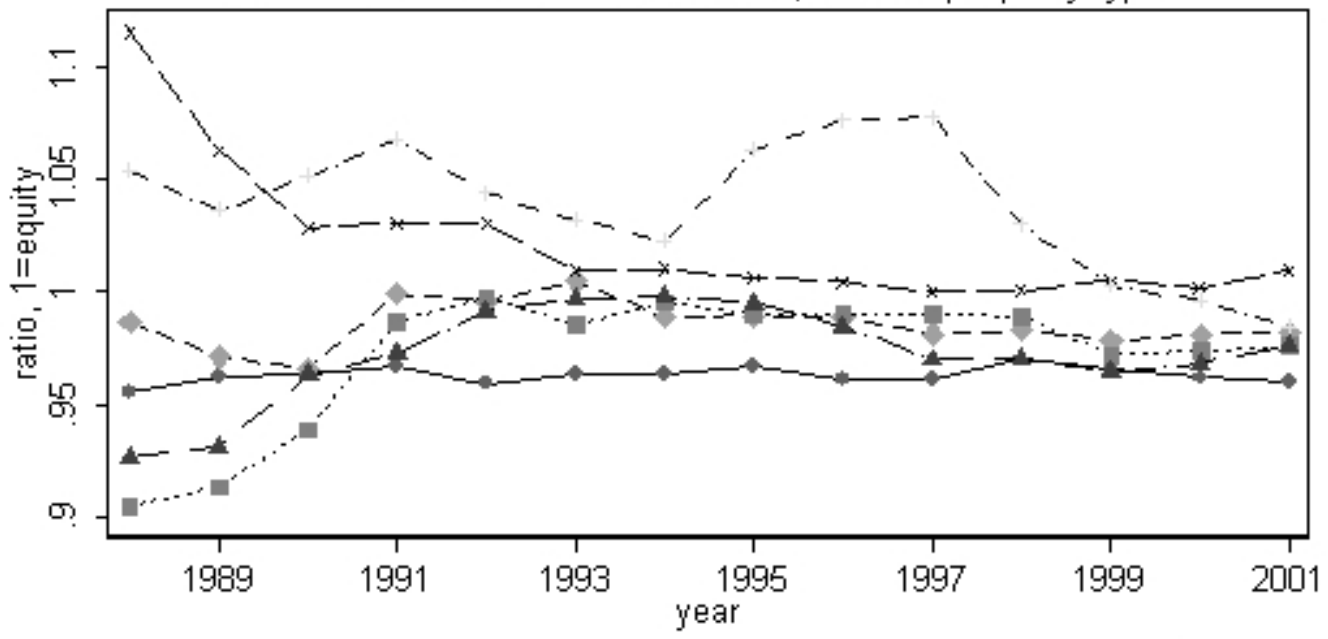

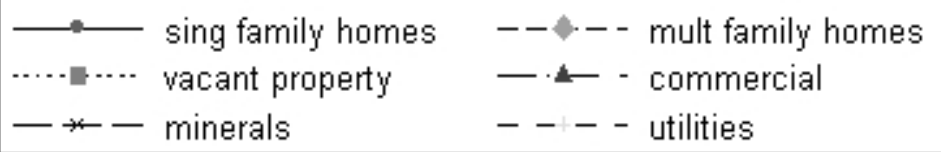

Figure 15

Effect of Robin Hood on Assessment Ratios, Single Family Hom

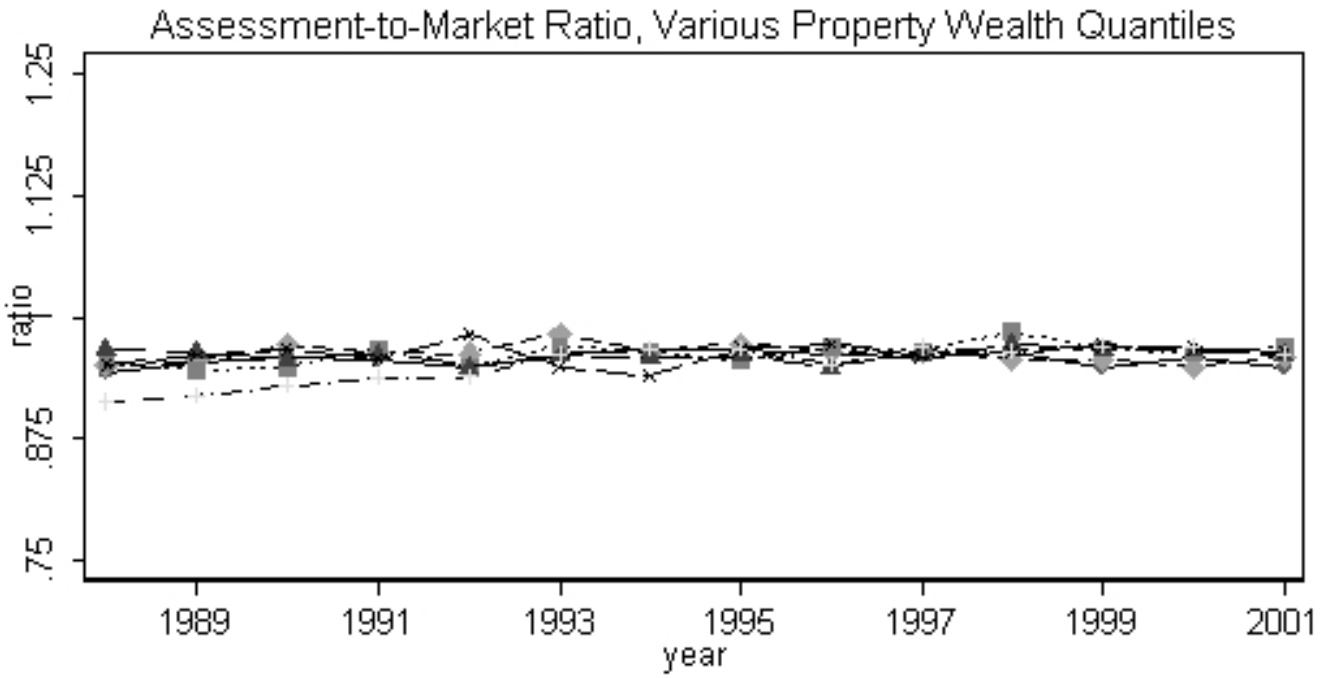

\begin{tabular}{|c|c|c|}
\hline$\rightarrow$ & Qua & tile 19 \\
\hline$\cdots$ & $Q$ & — - - Quantile 10 \\
\hline & Quar & $---\cdot$ \\
\hline
\end{tabular}


Figure 16

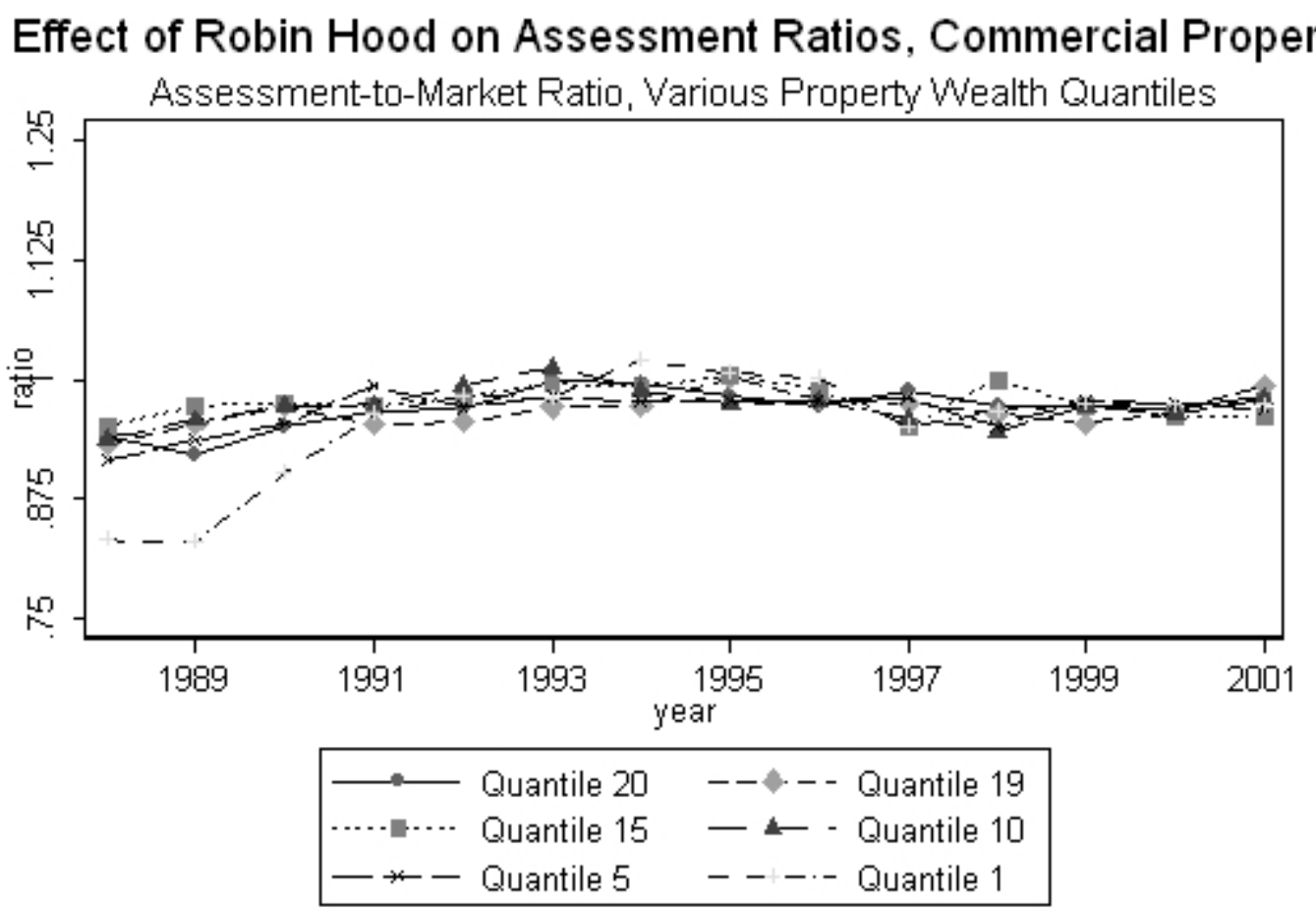

Figure 17

Effect of Robin Hood on Assessment Ratios, Mineral Property

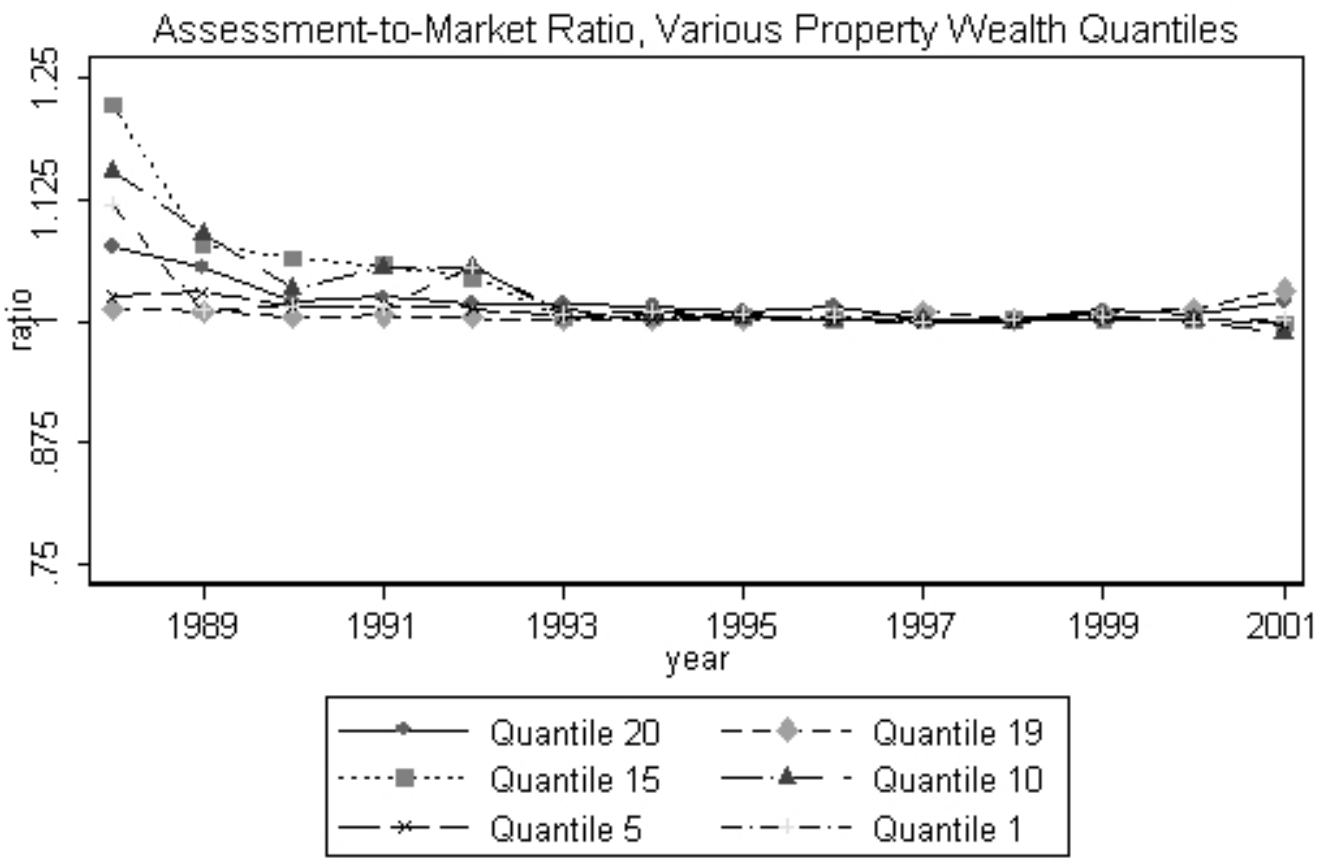


Figure 18

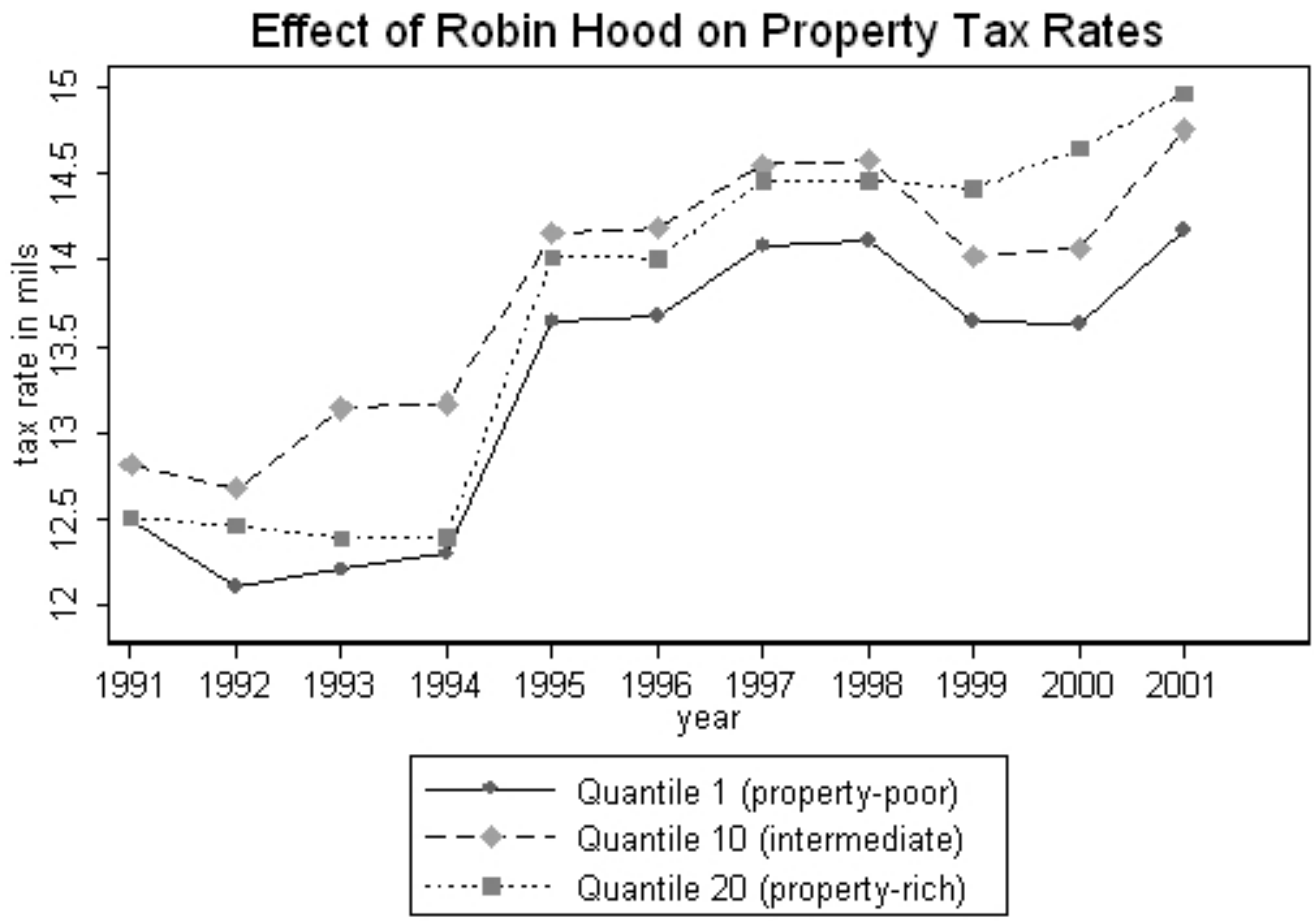

Figure 19

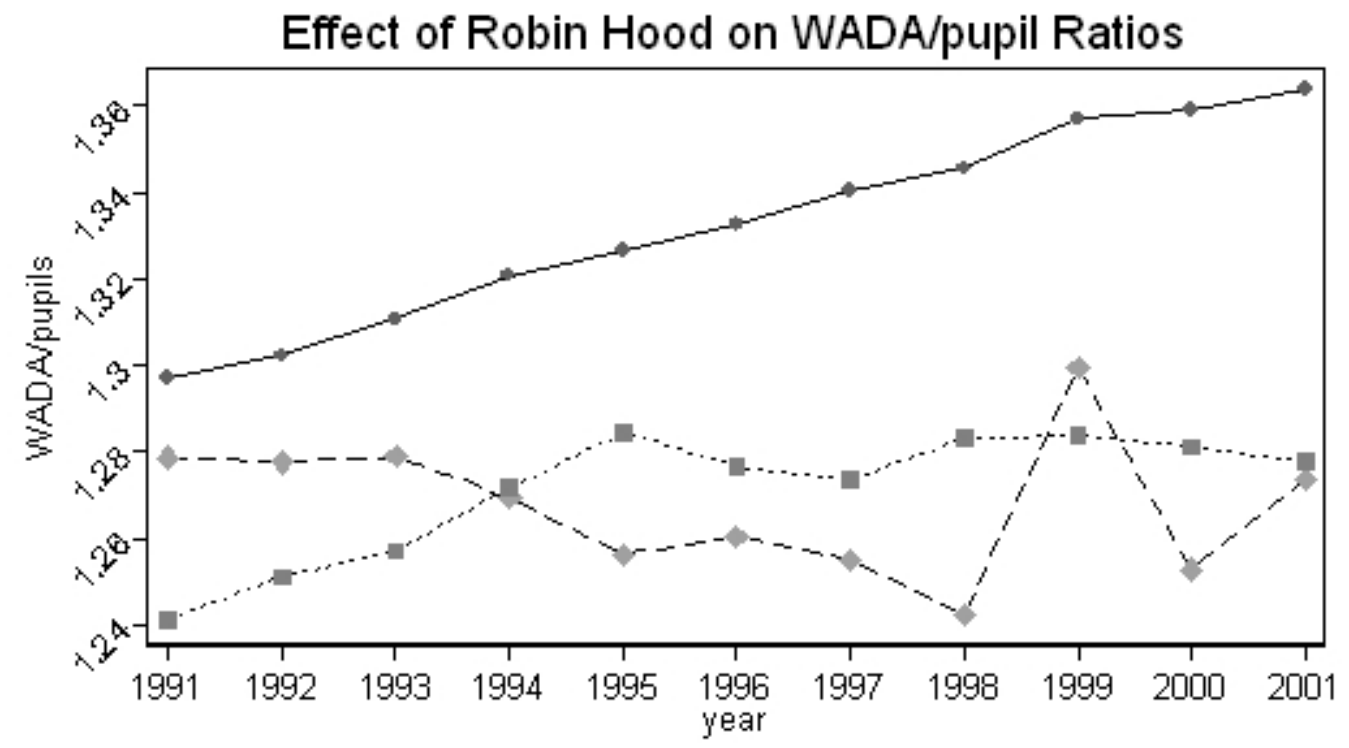

$\longrightarrow$ Property-Poor Districts that Can Get Increased Rev Only thru WACA

- - - - Intermediate Districts that Get Some Rev thru WADA

…....... Property-Rich Districts that Can Get Increased Rev Only thru WADA 
Figure 20

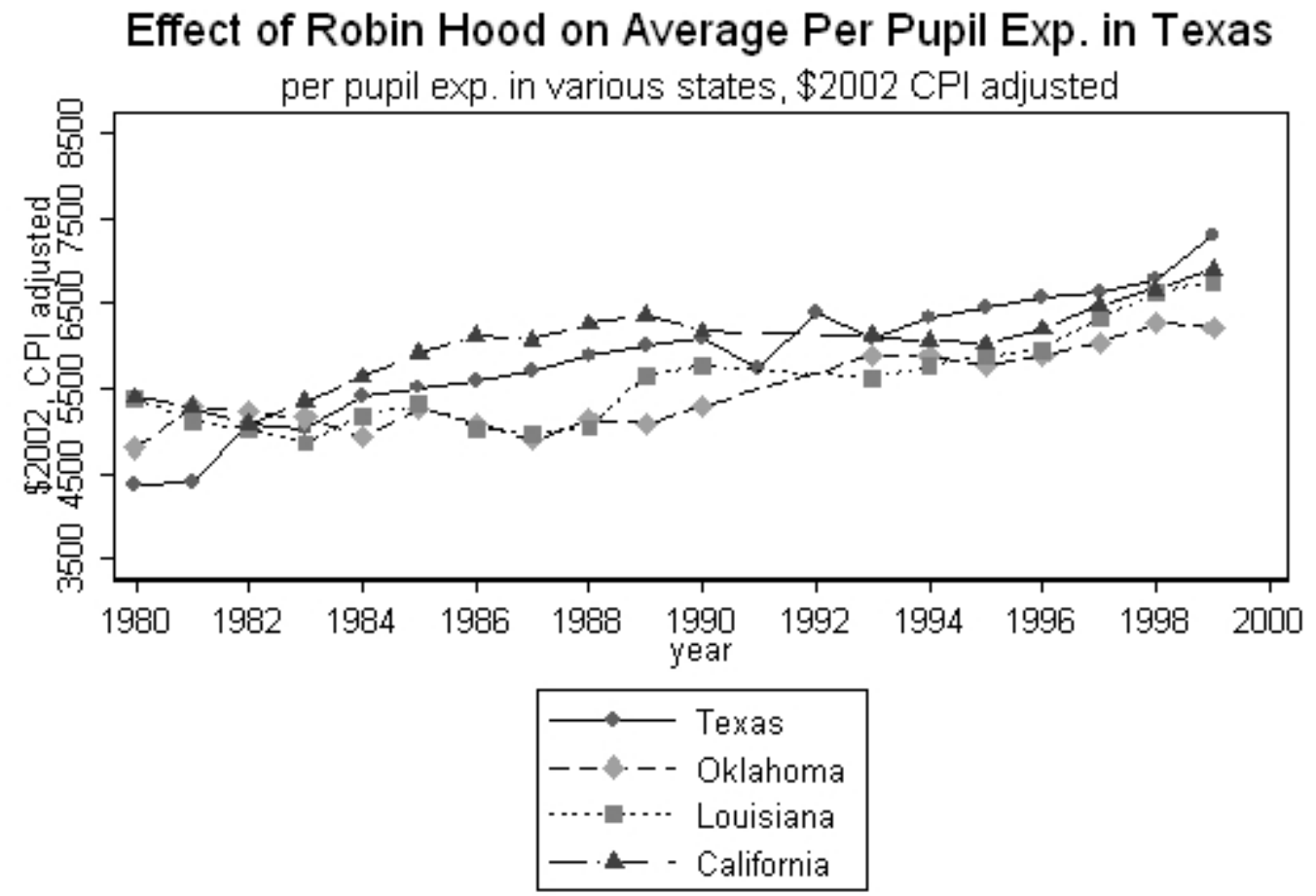

Figure 21

Effect of Robin Hood on Per Pupil Exp. as \% of Texas Income per pupil exp. divided by two measures of Texas income

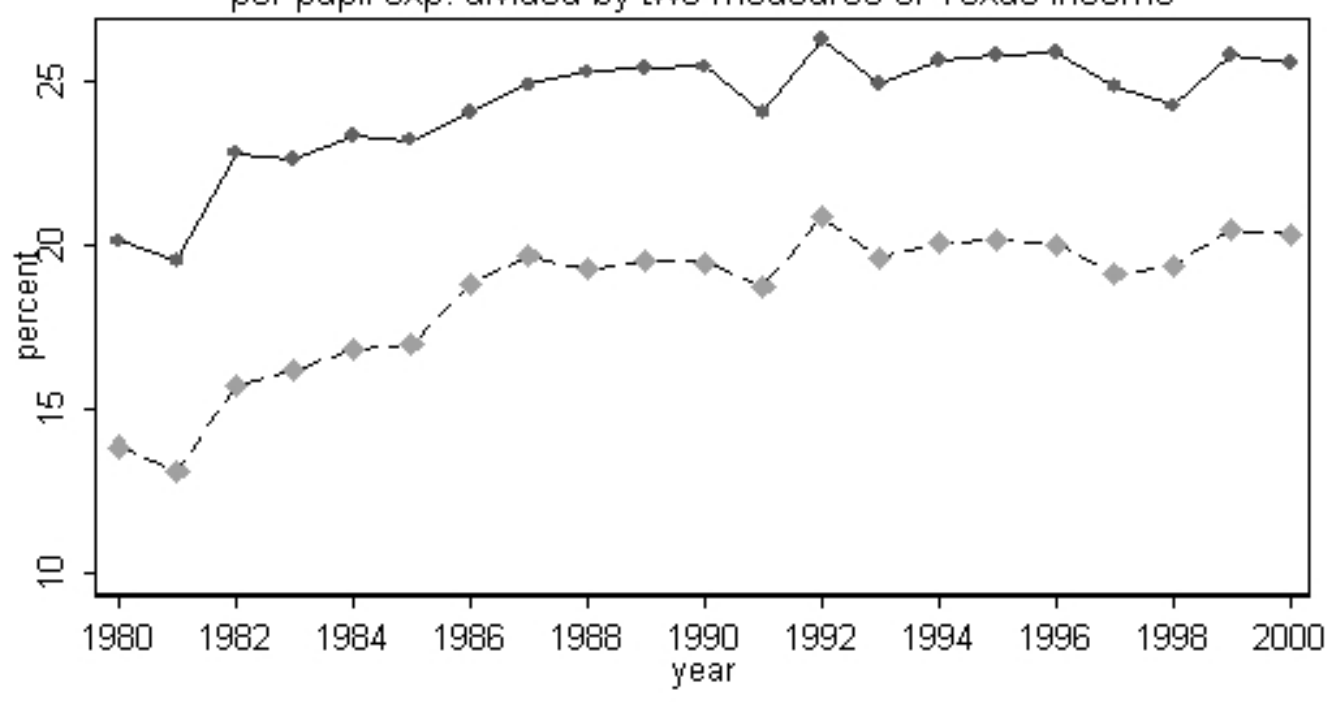

- - average per-pupil exp as \% of per-capita personal income $--\bullet-$ average per-pupil exp as \% of per-capita gross state pdt 
Figure 22

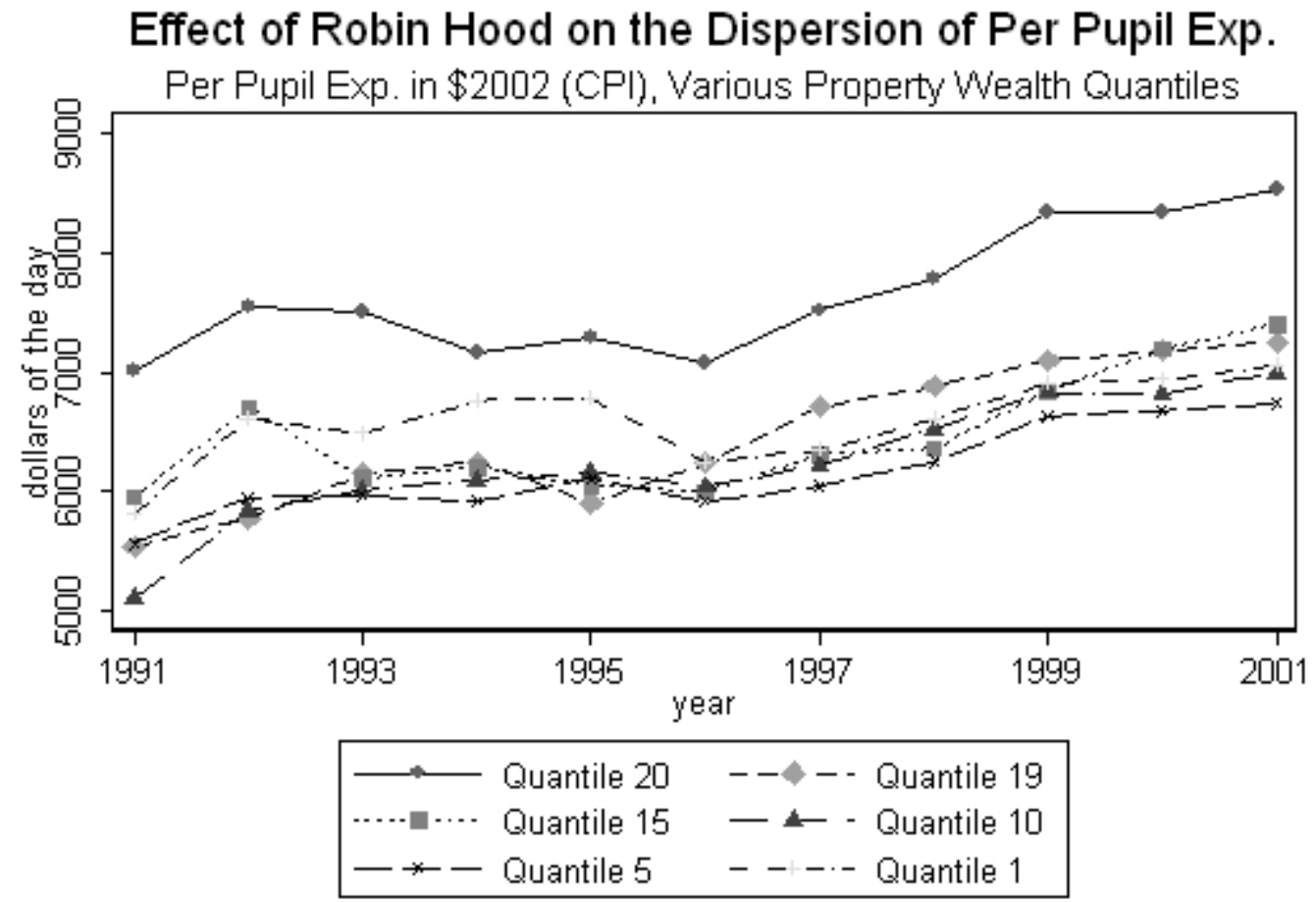


Table 1

Parameters of Texas' School Finance System, Before and After Robin Hood for Exemplary Property-Poor and Property-Rich Districts

\begin{tabular}{|c|c|c|c|}
\hline & & Tax & \\
\hline District & Median Family Income in $1989^{a}$ & Before Robin Hood & After Robin Hood \\
\hline $\begin{array}{l}\text { Edgewood } \\
\text { (Bexar County) }\end{array}$ & $\$ 22,945$ & 9.8 & 15.0 \\
\hline $\begin{array}{l}\text { Alamo Heights } \\
\text { (Bexar County) }\end{array}$ & $\$ 53,078$ & 12.4 & 15.0 \\
\hline
\end{tabular}

\begin{tabular}{|c|c|c|c|c|c|c|c|c|c|}
\hline \multirow{5}{*}{ District } & \multirow{5}{*}{$\begin{array}{l}\text { Before } \\
\text { Robin } \\
\text { Hood }\end{array}$} & \multicolumn{2}{|c|}{ Marginal Tax Price } & \multicolumn{3}{|c|}{$\begin{array}{c}\text { Lump Sum Transfer: } \\
\text { Foundation Aid Per Pupil } \\
\text { Minus } \\
\text { Effective Lump Sum Confiscated Per Pupil }{ }^{\mathrm{a}}\end{array}$} & \multicolumn{3}{|c|}{$\begin{array}{c}\text { District Keeps This Share of the Change in } \\
\text { Property Taxes When Its Property Values } \\
\text { Change (share kept) }\end{array}$} \\
\hline & & \multirow{3}{*}{\multicolumn{2}{|c|}{$\begin{array}{l}\text { After } \\
\text { Robin } \\
\text { Hood }\end{array}$}} & Before & \multirow{3}{*}{\multicolumn{2}{|c|}{$\begin{array}{l}\text { After } \\
\text { Robin } \\
\text { Hood }\end{array}$}} & \multirow{4}{*}{$\begin{array}{l}\text { Before } \\
\text { Robin } \\
\text { Hood }\end{array}$} & \multirow{3}{*}{\multicolumn{2}{|c|}{$\begin{array}{l}\text { After } \\
\text { Robin } \\
\text { Hood }\end{array}$}} \\
\hline & & & & Robin & & & & & \\
\hline & & & & Hood & & & & & \\
\hline & & $\begin{array}{r}\text { Intended } \\
\text { (no effects of } \\
\text { endogenous } \\
\text { capitalization) }\end{array}$ & $\begin{array}{r}\text { Actual } \\
\text { (includes } \\
\text { effects of } \\
\text { capitalization) }\end{array}$ & & $\begin{array}{r}\text { Intended } \\
\text { (no effects of } \\
\text { endogenous } \\
\text { capitalization) }\end{array}$ & $\begin{array}{r}\text { Actual } \\
\text { (includes } \\
\text { effects of } \\
\text { capitalization) }\end{array}$ & & $\begin{array}{r}\text { Intended } \\
\text { (no effects of } \\
\text { endogenous } \\
\text { capitalization). }\end{array}$ & $\begin{array}{r}\text { Actual } \\
\text { (includes } \\
\text { effects of } \\
\text { capitalization) }\end{array}$ \\
\hline $\begin{array}{l}\text { Edgewood } \\
\text { (Bexar County) }\end{array}$ & 1.00 & 0.11 & 0.11 & $\$ 3,187$ & $\$ 3,740$ & $\$ 3,732$ & 0.33 & 0.00 & 0.00 \\
\hline $\begin{array}{l}\text { Alamo Heights } \\
\text { (Bexar County) }\end{array}$ & 1.00 & 2.56 & 1.39 & 0 & $-15,041$ & $-3,573$ & 1.00 & 0.00 & 0.00 \\
\hline
\end{tabular}

a. 2002 dollars, adjusted using Bureau of Labor Statistics, Consumer Price Index.

Notes: Edgewood is a property-poor district that was in the lowest 5 percent of property value per student before Robin Hood. Alamo Heights is a property-rich district that was in the highest 5 percent of property value per student before Robin Hood. 1988-89 is the"before" year for Robin Hood. It is best because it predates all changes in school finance legislation. 1997 is a fairly typical year "after" the full implementation of Robin Hood: we could substitute 1994 through 1996 without changing the substance of the table. The source is authors' calculations based on United States Department of Education (1994), Texas Education Agency, Summary of Finances (various years). 
Table 2

Parameters of Texas' School Finance System, Before and After Robin Hood, for 20 Quantiles of the Property Wealth Distribution

\begin{tabular}{|c|c|c|c|c|c|c|}
\hline \multirow[b]{2}{*}{$\begin{array}{l}\text { Quantile (of property } \\
\text { wealth per pupil) }\end{array}$} & \multicolumn{2}{|c|}{ Marginal Tax Price } & \multicolumn{2}{|c|}{$\begin{array}{c}\text { Lump Sum Transfer: } \\
\text { Foundation Aid Per Pupil Minus } \\
\text { Effective Lump Sum Confiscation Per Pupil }\end{array}$} & \multicolumn{2}{|c|}{$\begin{array}{c}\text { District Keeps This Share of the Change in } \\
\text { Property Taxes When Its Property Values } \\
\text { Change (share kept) }\end{array}$} \\
\hline & $\begin{array}{c}\text { Before Robin } \\
\text { Hood }\end{array}$ & $\begin{array}{c}\text { After Robin } \\
\operatorname{Hood}\left(\text { Actual }^{b}\right)\end{array}$ & $\begin{array}{c}\text { Before Robin } \\
\text { Hood }\end{array}$ & $\begin{array}{c}\text { After Robin } \\
\text { Hood }\left(\text { Actual } 1^{b}\right)\end{array}$ & $\begin{array}{c}\text { Before Robin } \\
\text { Hood }\end{array}$ & $\begin{array}{c}\text { After Robin } \\
\text { Hood }\left(\text { Actual } 1^{b}\right)\end{array}$ \\
\hline $1=$ bottom $5 \%$ & 1.00 & 0.14 & $\$ 3,010$ & $\$ 3,676$ & 0.33 & 0.00 \\
\hline 2 & 1.00 & 0.19 & 2,842 & 3,396 & 0.36 & 0.00 \\
\hline 3 & 1.00 & 0.27 & 2,727 & 3,196 & 0.39 & 0.00 \\
\hline 4 & 1.00 & 0.31 & 2,654 & 3,082 & 0.45 & 0.00 \\
\hline 5 & 1.00 & 0.39 & 2,549 & 2,803 & 0.47 & 0.00 \\
\hline 6 & 1.00 & 0.39 & 2,529 & 2,813 & 0.56 & 0.00 \\
\hline 7 & 1.00 & 0.48 & 2,314 & 2,440 & 0.53 & 0.00 \\
\hline 8 & 1.00 & 0.52 & 2,231 & 2,318 & 0.55 & 0.00 \\
\hline 9 & 1.00 & 0.52 & 2,159 & 2,298 & 0.52 & 0.00 \\
\hline 10 & 1.00 & 0.53 & 2,236 & 2,331 & 0.54 & 0.00 \\
\hline 11 & 1.00 & 0.56 & 2,111 & 2,241 & 0.56 & 0.00 \\
\hline 12 & 1.00 & 0.61 & 1,968 & 2,080 & 0.53 & 0.01 \\
\hline 13 & 1.00 & 0.66 & 1,929 & 1,917 & 0.50 & 0.00 \\
\hline 14 & 1.00 & 0.73 & 1,761 & 1,680 & 0.59 & 0.01 \\
\hline $15-16^{\mathrm{c}}$ & 1.00 & 0.85 & 1,784 & 22 & 0.53 & 0.07 \\
\hline 17 & 1.00 & 0.95 & 1,494 & -32 & 0.56 & 0.09 \\
\hline 18 & 1.00 & 1.00 & 1,470 & -723 & 0.60 & 0.30 \\
\hline 19 & 1.00 & 1.25 & 1,082 & -873 & 0.58 & 0.01 \\
\hline $20=$ top $5 \%$ & 1.00 & 1.75 & 501 & $-3,350$ & 0.70 & 0.03 \\
\hline
\end{tabular}

a. 2002 dollars, adjusted using Bureau of Labor Statistics, Consumer Price Index.

b. Actual parameter, meaning that the parameter may reflect capitalization endogenous to Robin Hood.

c. Quantiles 15 and 16 cannot be separated because Houston, a district with very large enrollment, is on the margin between them. Each quantile represents about 5 percent of the students in Texas (about 150,000 students before Robin Hood). The precise number of students varies slightly from quantile to quantile because of districts with large enrollment.

Notes: 1988-89 is the"before" year for Robin Hood. It is best because it predates all school finance legislation. 1997 is a fairly typical year "after" the full implementation of Robin Hood: we could substitute 1994 through 1996 without changing the substance of the table. The column showing the net foundation aid minus the lump sum captured subtracts the amount captured if the recapture districts are to maintain their per pupil spending. The quantiles are based on 1991 property values and pupils. The table source is authors' calculations based on Texas Education Agency, Summary of Finances (various years). 
Table 3

\begin{tabular}{|c|c|c|c|c|}
\hline$\overline{\text { Year }}$ & $\begin{array}{l}\text { Confiscation Threshold } \\
\text { (dollars of day) }\end{array}$ & $\begin{array}{l}\text { Confiscation Threshold } \\
\text { (2002 dollars) }\end{array}$ & Texas Students in Confiscation Districts & $\begin{array}{l}\text { Predicted (in absence of Robin Hood) } \\
\text { Texas Students in Confiscation Districts }\end{array}$ \\
\hline 1994 & $\$ 280,000$ & $\$ 339,892$ & 5.1 & 11.6 \\
\hline 1995 & 280,000 & 330,525 & $5.2 \%$ & $12.8 \%$ \\
\hline 1996 & 280,000 & 321,045 & 6.0 & 13.7 \\
\hline 1997 & 280,000 & 313,844 & 5.8 & 12.8 \\
\hline 1998 & 280,000 & 309,031 & 6.5 & 13.2 \\
\hline 1999 & 295,000 & 318,550 & 6.5 & 17.5 \\
\hline 2000 & 295,000 & 308,191 & 8.3 & 17.3 \\
\hline 2001 & 300,000 & 304,743 & 9.0 & 19.2 \\
\hline 2002 & 305,000 & 305,000 & 10.3 & 22.1 \\
\hline
\end{tabular}

a. 2002 dollars, adjusted using Bureau of Labor Statistics, Consumer Price Index.

The source is authors' calculations based on Texas Education Agency, Summary of Finances (various years), Texas Education Agency, Academic Excellence Indicator System (various years) 
Table 4

Effects of "Robin Hood" School Finance Scheme on Property Values

dependent variable: $\ln$ (actual property tax base of district)

\begin{tabular}{|c|c|c|}
\hline & $\begin{array}{l}\text { Simulated Instrumental Variables } \\
\text { Estimates } \\
\text { (Treatment on the Treated Effects) }\end{array}$ & $\begin{array}{l}\text { Reduced Form Estimates } \\
\text { (Intention to Treat Effects) }\end{array}$ \\
\hline $\begin{array}{l}\ln (\text { marginal tax price }) \\
\text { if marginal tax price is } \geq 1^{\text {a }}\end{array}$ & $\begin{array}{l}-0.2483 \\
(0.0211)\end{array}$ & $\begin{array}{l}-0.1662 \\
(0.0109)\end{array}$ \\
\hline $\begin{array}{l}\ln (\text { marginal tax price }) \\
\text { if marginal tax price is }<1^{\text {a }}\end{array}$ & $\begin{array}{l}-0.0536 \\
(0.0054)\end{array}$ & $\begin{array}{l}-0.0448 \\
(0.0045)\end{array}$ \\
\hline $\ln ($ virtual lump sum grant) & $\begin{array}{c}0.0060 \\
(0.0008)\end{array}$ & $\begin{array}{c}0.0056 \\
(0.0007)\end{array}$ \\
\hline $\begin{array}{l}\text { share of the change in property taxes that district keeps when its property values } \\
\text { change (share kept) }\end{array}$ & $\begin{array}{c}0.1489 \\
(0.0113)\end{array}$ & $\begin{array}{c}0.1092 \\
(0.0082)\end{array}$ \\
\hline $\begin{array}{l}\text { predicted } \ln (\text { property tax base of district) } \\
\text { district fixed effects }\end{array}$ & $\begin{array}{l}\text { yes } \\
\text { yes }\end{array}$ & $\begin{array}{l}\text { yes } \\
\text { yes }\end{array}$ \\
\hline
\end{tabular}

a. Because a property-rich district facing an marginal tax price below 1 is losing its own money, which it would otherwise have spent, it may value the money more highly than a property-poor district that pays only a fraction of a dollar for every dollar it receives.

Note: 17,241 observations on 1,013 Texas school districts from 1984 to 2001 . Standard errors are in parentheses. The dependent variable is the natural log of the actual property tax base of a district and has mean 21.5 and standard deviation 1.82. Simulated parameters apply the school finance laws to predicted property values and thus do not allow endogenous capitalization to affect the results. Predicted property values come from estimates of equation (1) in the text. 
Table 5

Effects of "Robin Hood" School Finance Scheme on Per Pupil Spending

dependent variable: $\ln$ (per pupil spending of district)

\begin{tabular}{|c|c|c|}
\hline & $\begin{array}{l}\text { Simulated Instrumental Variables } \\
\text { Estimates } \\
\text { (Treatment on the Treated Effects) }\end{array}$ & $\begin{array}{l}\text { Reduced Form Estimates } \\
\text { (Intention to Treat Effects) }\end{array}$ \\
\hline $\begin{array}{l}\ln (\text { marginal tax price }) \\
\text { if marginal tax price is } \geq 1^{\text {a }}\end{array}$ & $\begin{array}{l}-0.0500 \\
(0.0300)\end{array}$ & $\begin{array}{l}-0.0002 \\
(0.0164)\end{array}$ \\
\hline $\begin{array}{l}\ln (\text { marginal tax price }) \\
\text { if marginal tax price is }<1^{\text {a }}\end{array}$ & $\begin{array}{l}-0.1356 \\
(0.0093)\end{array}$ & $\begin{array}{l}-0.1514 \\
(0.0076)\end{array}$ \\
\hline $\ln ($ virtual lump sum grant) & $\begin{array}{c}0.0090 \\
(0.0010)\end{array}$ & $\begin{array}{c}0.0094 \\
(0.0010)\end{array}$ \\
\hline $\begin{array}{l}\text { share of the change in property taxes that district keeps when its property values } \\
\text { change (share kept) }\end{array}$ & $\begin{array}{l}-0.0273 \\
(0.0021)\end{array}$ & $\begin{array}{l}-0.0244 \\
(0.0014)\end{array}$ \\
\hline $\begin{array}{l}\text { predicted } \ln \text { (property tax base of district) } \\
\text { district fixed effects }\end{array}$ & $\begin{array}{l}\text { yes } \\
\text { yes }\end{array}$ & $\begin{array}{l}\text { yes } \\
\text { yes }\end{array}$ \\
\hline
\end{tabular}

a. Because a property-rich district facing an marginal tax price below 1 is losing its own money, which it would otherwise have spent on something it valued in schools, the marginal tax price may have a greater effect on a property-rich district than on a property-poor district, which pays for only a fraction of every dollar it spends.

Note: 17,241 observations on 1,013 Texas school districts from 1984 to 2001 . Standard errors are in parentheses. The dependent variable is the natural log of the actual property tax base of a district and has mean 21.5 and standard deviation 1.82. Simulated parameters apply the school finance laws to predicted property values and thus do not allow endogenous capitalization to affect the results. Predicted property values come from estimates of equation (1) in the text. 
Table 6

Cost - Benefit Indicators for the Robin Hood School Finance Scheme

\begin{tabular}{|c|c|c|c|c|}
\hline \multicolumn{2}{|c|}{ Benefits of Robin Hood } & $\begin{array}{l}\text { Remaining School } \\
\text { Spending Gap }\end{array}$ & \multicolumn{2}{|c|}{ Costs of Robin Hood } \\
\hline $\begin{array}{l}0.11 \text { decline in the } \\
\text { coefficient of } \\
\text { variation in per-pupil } \\
\text { spending }\end{array}$ & $\begin{array}{c}\$ 500 \text { decline in the } \\
\text { spending gap between } \\
\text { the highest and lowest } \\
\text { quantile districts }\end{array}$ & $\begin{array}{l}\$ 1,482 \text { per pupil } \\
\text { needed to let every } \\
\text { Texas district at } \\
\text { spending level of top } \\
\text { quantile } \text { districts }^{\text {a }}\end{array}$ & $\begin{array}{c}\text { as a stock: } \\
\$ 27,000 \\
\text { per pupil }\end{array}$ & $\begin{array}{l}\text { as a flow: } \\
\$ 1,350 \\
\text { per pupil }\end{array}$ \\
\hline
\end{tabular}

a. 20 quantiles are defined based on property value per pupil.

b. Assuming the stock is invested indefinitely with an annual return of 5 percent. 
Appendix Figure 1

Percent of Property that is Land and Residential, Quantile Quantile 1 is property poorest, Quantile 20 is property richest

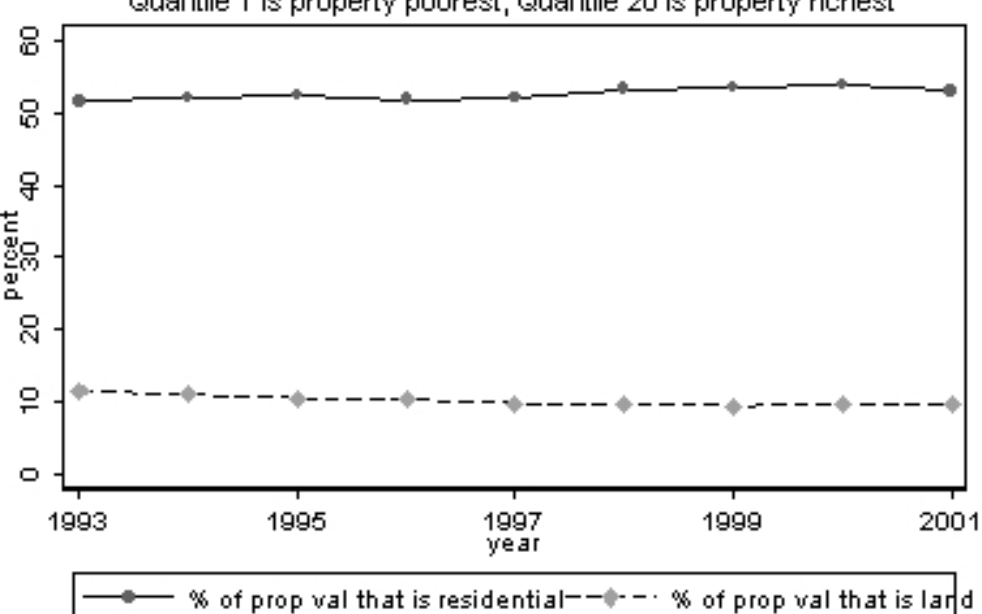

Appendix Figure 2

Percent of Property that is Land and Residential, Quantile Quantile 1 is property poorest, Quantile 20 is property richest

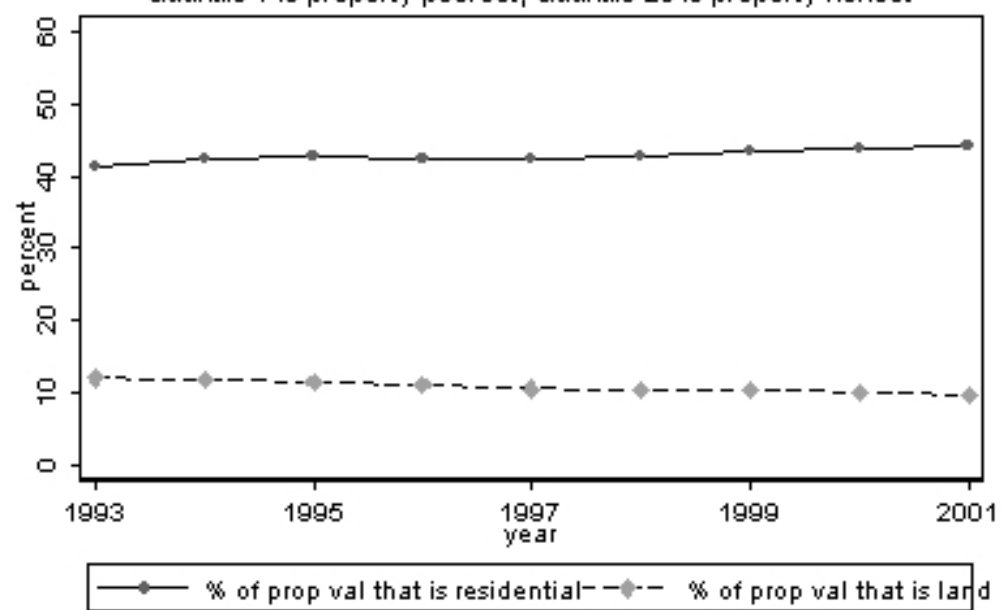

Appendix Figure 3

Percent of Property that is Land and Residential, Quantile 2

Quantile 1 is property poorest, Quantile 20 is property richest

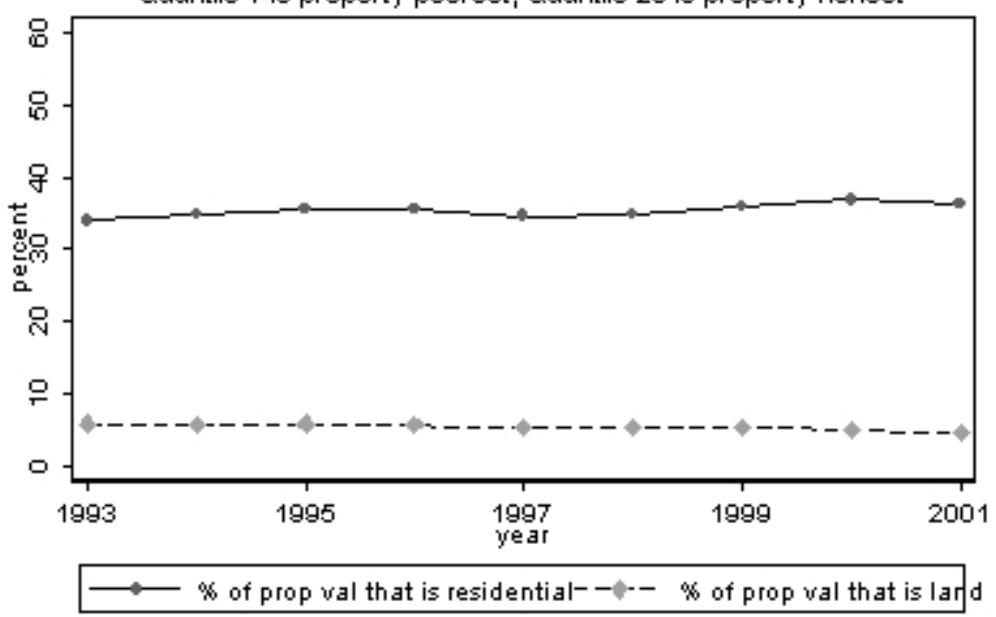


Appendix Table 1

Regression Results: Determinants of the Number of Housing Units in Texas School Districts Dependent Variable: decadal change in ln(housing units) in district

\begin{tabular}{|c|c|c|}
\hline & Coefficient & $\overline{\text { Standard Error }}$ \\
\hline decadal change in $\ln$ (population) in metro area/county & $0.927 * *$ & 0.049 \\
\hline indicator: change is over the 1990 s decade & $-0.423 * *$ & 0.063 \\
\hline indicator: district in lowest quantile of property wealth per pupil & $0.349 * *$ & 0.062 \\
\hline indicator: district in quantile 2 of property wealth per pupil & $0.616^{* *}$ & 0.042 \\
\hline indicator: district in quantile 3 of property wealth per pupil & $0.537 * *$ & 0.034 \\
\hline indicator: district in quantile 4 of property wealth per pupil & $0.491 * *$ & 0.028 \\
\hline indicator: district in quantile 5 of property wealth per pupil & $0.462 * *$ & 0.032 \\
\hline indicator: district in quantile 6 of property wealth per pupil & $0.424 * *$ & 0.042 \\
\hline indicator: district in quantile 7 of property wealth per pupil & $0.503 * *$ & 0.043 \\
\hline indicator: district in quantile 8 of property wealth per pupil & $0.393 * *$ & 0.050 \\
\hline indicator: district in quantile 9 of property wealth per pupil & $0.445 * *$ & 0.045 \\
\hline indicator: district in quantile 10 of property wealth per pupil & $0.476^{* *}$ & 0.040 \\
\hline indicator: district in quantile 11 of property wealth per pupil & $0.524 * *$ & 0.037 \\
\hline indicator: district in quantile 12 of property wealth per pupil & $0.582 * *$ & 0.044 \\
\hline indicator: district in quantile 13 of property wealth per pupil & $0.497 * *$ & 0.069 \\
\hline indicator: district in quantile 14 of property wealth per pupil & $0.527 * *$ & 0.063 \\
\hline indicator: district in quantiles $15-16$ of property wealth per pupil & $0.492 * *$ & 0.040 \\
\hline indicator: district in quantile 17 of property wealth per pupil & $0.508 * *$ & 0.050 \\
\hline indicator: district in quantile 18 of property wealth per pupil & $0.632 * *$ & 0.045 \\
\hline indicator: district in quantile 19 of property wealth per pupil & $0.336^{* *}$ & 0.071 \\
\hline indicator: district in highest quantile of property wealth per pupil & $0.539 * *$ & 0.029 \\
\hline interaction: $1990 \mathrm{~s}$ decade $\cdot$ quantile 1 & 0.114 & 0.107 \\
\hline interaction: $1990 \mathrm{~s}$ decade $\cdot$ quantile 2 & -0.048 & 0.087 \\
\hline interaction: $1990 \mathrm{~s}$ decade $\cdot$ quantile 3 & -0.097 & 0.079 \\
\hline interaction: $1990 \mathrm{~s}$ decade $\cdot$ quantile 4 & -0.034 & 0.075 \\
\hline interaction: $1990 \mathrm{~s}$ decade $\cdot$ quantile 5 & -0.036 & 0.077 \\
\hline interaction: $1990 \mathrm{~s}$ decade $\cdot$ quantile 6 & -0.002 & 0.086 \\
\hline interaction: $1990 \mathrm{~s}$ decade $\cdot$ quantile 7 & -0.043 & 0.088 \\
\hline interaction: $1990 \mathrm{~s}$ decade $\cdot$ quantile 8 & 0.071 & 0.095 \\
\hline interaction: $1990 \mathrm{~s}$ decade $\cdot$ quantile 10 & -0.055 & 0.084 \\
\hline interaction: $1990 \mathrm{~s}$ decade $\cdot$ quantile 11 & -0.076 & 0.082 \\
\hline interaction: $1990 \mathrm{~s}$ decade $\cdot$ quantile 12 & -0.102 & 0.088 \\
\hline interaction: $1990 \mathrm{~s}$ decade $\cdot$ quantile 13 & -0.024 & 0.114 \\
\hline interaction: $1990 \mathrm{~s}$ decade $\cdot$ quantile 14 & -0.004 & 0.109 \\
\hline interaction: 1990 s decade $\cdot$ quantiles $15-16$ & -0.061 & 0.084 \\
\hline interaction: $1990 \mathrm{~s}$ decade $\cdot$ quantile 17 & -0.036 & 0.094 \\
\hline interaction: $1990 \mathrm{~s}$ decade $\cdot$ quantile 18 & -0.156 & 0.090 \\
\hline interaction: $1990 \mathrm{~s}$ decade $\cdot$ quantile 19 & $0.211 *$ & 0.116 \\
\hline interaction: $1990 \mathrm{~s}$ decade $\cdot$ quantile 20 & -0.079 & 0.075 \\
\hline
\end{tabular}

Notes: The observations are at the district level. The decadal changes are 2000 minus 1990 or 1990 minus 1980. See regression equation in text. ** $(*)$ Coefficient is statistically significantly different from zero at the $5 \%(10 \%)$ level. The quantiles are based on 1991 property values and pupils. Quantile 9 is the omitted category for the interaction terms. Quantiles 15 and 16 cannot be separated because Houston, a district with very large enrollment, is on the margin between them. Each quantile represents about 5 percent of the students in Texas (about 150,000 students before Robin Hood). The precise number of students varies slightly from quantile to quantile because of districts with large enrollment. The number of housing units comes from census data aggregated to the school district level: United States Department of Commerce (1983, 2003), United States Department of Education (1994). The other data sources are Texas Education Agency, Summary of Finances (various years) and United States Department of Commerce (2004). 